\title{
Copper and Gold Mineralization Features in Deh Bala Region-South of Takestan
}

\author{
Mohammad Yousefi' ${ }^{1}$, Nematollah Rashidnejad Omran', Mohammad Lotfi ${ }^{2}$, \\ Mohammad Hassan Bazoobandi ${ }^{3}$ \\ ${ }^{1}$ Department of Geology, Faculty of Science, Tarbiat Modares University, Tehran, Iran \\ ${ }^{2}$ Islamic Azad University, Tehran North Branch, Tehran, Iran \\ ${ }^{3}$ Faculty of Science, Shahid Sherafat, University of Farhangian, Tehran, Iran \\ Email:m.yousefi@modares.ac.ir, rashid@modares.ac.ir,m_lotfi_1014@yahoo.com,m_bazoobandi@yahoo.com
}

How to cite this paper: Yousefi, M., Omran, N.R., Lotfi, M. and Bazoobandi, M.H. (2017) Copper and Gold Mineralization Features in Deh Bala Region-South of Takestan. Open Journal of Geology, 7, 1022-1046. https://doi.org/10.4236/ojg.2017.77069

Received: April 22, 2017

Accepted: July 24, 2017

Published: July 27, 2017

Copyright () 2017 by authors and Scientific Research Publishing Inc. This work is licensed under the Creative Commons Attribution International License (CC BY 4.0).

http://creativecommons.org/licenses/by/4.0/

Open Access

\begin{abstract}
The studied area is located in $30^{\text {th }} \mathrm{km}$ of Bouien-Zahra road in Saveh in southern border of Khiaraj 1:100,000 Geology map rectangle (Danesfahan) in South of Takestan of Iran. This area is a part of volcano-plutonic belt of Urumia-Dokhtar. Rocky outcrops in this area are mainly in two types of volcanic and plutonic. Volcanic Rocks with the age of Eocene are Trachyte to trachyandesite and andesite to basalt-andesite. Plutonic stones with the age of Oligo-Miocene to Miocene are in types of quartz diorite, quartz monzonite, Monzonite and Semi-acidic volcanic domes and granite aplite. Due to having dominant fault systems with trends of NW-SE and NE-SW in an intersectional manner in this area, vein-veinlets Siliciclastic sulfide mineralization can be observed in line with the same faults. Monzonite intrusive rocks are considered as host stone of these mineralizations. The information obtained from field observations and laboratory studies confirms the main alteration along with mineralization in types of silicic and pyrite, sericite, carbonate, argillic and propylitic. Mineralogy Paragenesis in the study area includes Pyrite, chalcopyrite, bornite, colitis, malachite, hematite and goethite and the most important Gang minerals including quartz, calcite, albite, sericite, kaolinite, pyrophyllite, epidote, alunite and jarosite, and according to carried out studies, copper, gold and silver are among mineralizing elements and elements such as molybdenum, cadmium, arsenic and mercury show anomalies as accompanying and guidance elements in some of the samples. The grade of copper in this area in sulfide siliciclastic veins is $1 \%$ to $3 \%$ and the grade of gold is $130 \mathrm{ppm}$ and the grade of silver is reportable from $0.5 \mathrm{ppm}$ to $6 \mathrm{ppm}$. Based on the geothermometry studies of fluid inclusions, homogenization temperature from $150^{\circ} \mathrm{C}$ to $300^{\circ} \mathrm{C}$ and the salinity grade from 4 to 5.5 percent indicate the fact that an epithermal hydrothermal system in final stages controls the mineralization of the area.
\end{abstract}




\section{Keywords}

Mineralization, Epithermal, Geochemical, Alteration, Copper, Gold, South of Takestan

\section{Introduction}

Porphyry $\mathrm{Cu} \pm \mathrm{Mo} \pm \mathrm{Au}$ and related epi thermal Au deposits are intrusion centered, and are formed at $\leq 4$ and $\leq 1 \mathrm{~km}$ depth, respectively, by fluids exsolved from magmas emplaced at $\sim 5-10 \mathrm{~km}$ depth in the upper crust [1]. The majority of known deposits are genetically related to intermediate to felsic calc alkaline magmas in volcano plutonic arcs above active subduction zones (Figure 1(a)). They are thus directly linked to the petrogenesis of arc magmas, and derive their fundamental characteristics (e.g., relatively high oxidation state and enrichments
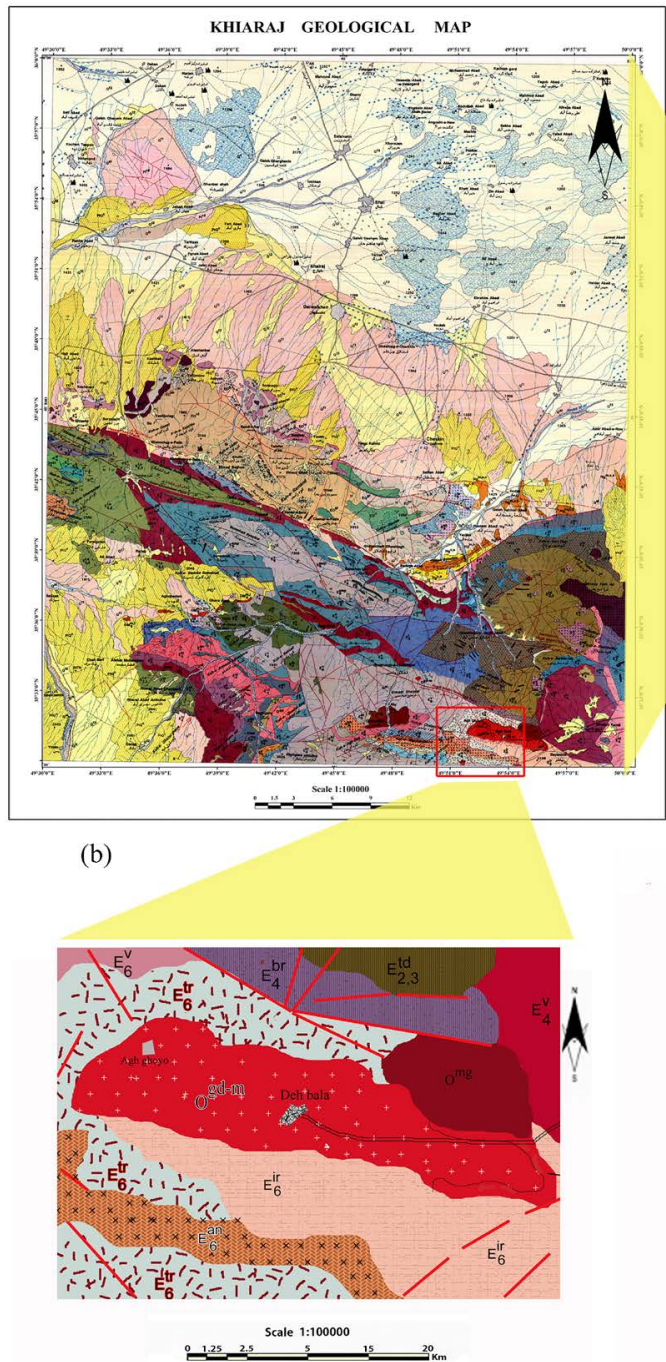

(a)

LE G E N D

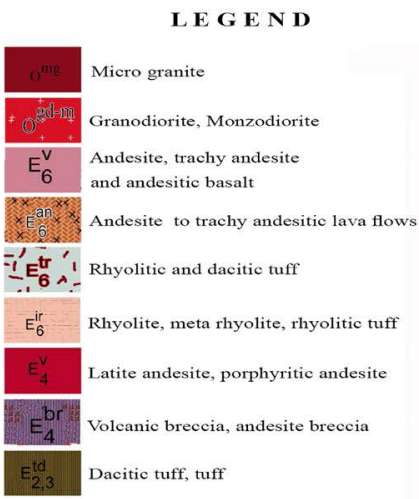

(d)

Figure 1. (a) Geological position of the studied area in Iran's map; (b) the position of the are in Khiaraj 1:100,000 rectangle; (c) the studied area; (d) guidance. 
in alkalines, $\mathrm{S}, \mathrm{Cl}, \mathrm{H}_{2} \mathrm{O}$, and some metals) from subduction processes. Arc magmas are predominantly formed by partial melting of the metasomatized wedge of asthenospheric mantle between the down going oceanic and overriding oceanic or continental plates [2]. Two characteristics (high oxidation, high water content) are critical to the formation of magmatic-hydrothermal ore deposits [3] and the high oxidation state suppresses the formation of significant amounts of magmatic sulfide phases, which would strip the magma of chalcophile and siderophile metals [4]; and the high water content results in saturation of the magma in an aqueous fluid phase upon ascent into the upper crust, into which these metals will efficiently partition [5]. Although magmas with these characteristics most commonly form directly in response to inputs from the subduction zone, it is also possible to extract compositionally and isotopically similar magmas from upper plate lithosphere that has been modified by prior subduction processes, but with melting caused by later post-subduction events [6].

Epithermal gold reserves along with acidic pyroclastic rocks and Tertiary calc-alkaline intermediate can be found in drought environment which have appeared in. Also, their tectonic setting is mainly subduction zone belts and areas behind the arc. Advanced argillic alterations, Cystic, alunite, silica and propylitic can be observed in such environment which usually shows anomalies of copper and other metals (including gold) [7]. Ellndio mines in South America, Lepanto in the US and Nansatsu in Japan are among the most important epithermal gold mines in the world [8].

Mines such as Sarcheshmeh, Meydouk, Darrezar, ChaharGonbad, Sarkouh, Goudkalvari, Songon, Keyghal, Gal'e Zari and Darestan copper and gold are also among epithermal gold mines and Porphyre Copper-Gold of Iran which many have them have structural and genetic The studied area has been located in 30th $\mathrm{km}$ of bouien Zahra-Saveh road in southern border of Khiaraj 1:100,000 Geological map Danesfahan [9] in South of Takestan. Based on the tectonic sedimentary division of Iran's environments, this area is considered as Tectono zone of Urmia-Dokhtar [10] or Tabriz-Bazman [11] (Figure 1).

This article tries to provide acceptable results by reviewing and studying the Deh Bala area. Detailed study and evaluation of this area in terms of geology, alteration and mineralization, fluid inclusion and type of mineralization can help researchers to study and explore other parts similar to Urmia-Dokhtar zone.

\section{Methodology}

Petrographic, Mineralization and Mineralography, Geochemistry and Geothermometry evaluations are the main objectives of this study. Airborne geophysical data using magnetometer method (Geological Survey of Iran) has been used for this objective for carrying out better studies with larger view after collecting and reviewing all basic information about the mentioned area as well as processing satellite images using appropriate software in GIS and RS systems in order to determine alteration zones and appropriate locations for sampling. In addition to Field studies and taking Samples of surface and several heavy mineral samples 
from the waterways, the best samples for laboratory studies were selected and petrographic and Mineralography studies were carried out and some samples were selected for XRD and XRF analysis and atomic absorption analysis and fluid inclusions (Tarbiat Modares University), the study of electron microscopy (SEM) (Amirkabir University of Technology) and heavy mineral analysis (Geological Survey of Iran).

\section{Geology of the Area}

The study area is located in volcanic-plutonic belt or magmatic arc of UrmiaDokhtar which has stretched from the North West to the South East with a trend (Figure 1). Pyroclastic volcanic stone units have Eocene in this area which has been cut by Oligo-Miocene intrusive. Volcanic activity in this belt has originally started in the Cretaceous which reaches it most severe intensity is in the Eocene period [12]. The eruptions of these lavas are in calc-alkaline type and a variety of volcanic stones such as basalt, andesite, andesite and rhyolite have been formed after it with different volumes.

According to Khiaraj 1:100,000 map, there is an alternation of volcaniclastic and volcanic stones including dacitic tuffs and andesite, Ignimbrite tuffs, andesitic lavas to trachyandesite and granodiorite intrusions, monzonite and Micro granite outcrop.

\section{Petrography}

\subsection{Volcanic Rocks}

Layered volcanic stones can be observed on the sidelines of the Subvolcanic mass. Andesite to Basaltic andesite is dark green with empty holes or filled with secondary minerals showing emissions with porphyritic texture in Microliteglass (somewhat open crystallized) underlying along with numerous epoch oxide minerals (small and large, shaped and amorphous). Phenocrysts are mainly Kf and $\mathrm{Pl}$ along with Bio and $\mathrm{Am}$, all of which have inclusions of epoch mineral which is mainly iron oxide.

Fine-grained quartz crystals are present to a lesser extent with which are sometimes the reaction product. Mafic Fen crystals (Am or Bio) have been badly damaged and carry more opaque (and quartz) than other minerals (Figure 2).

Outcrops with lighter color also have porphyry texture, the difference is that they have more intense alteration and less opaque mineral. The main minerals can be observed more in these stones with presence of epidote, calcite and sphere. This stone has trachyte to trachyandesite composition (Figure 3). The type of Twining in this stone indicates the tectonic stresses imposed on the stone.

\subsection{Intrusive Rocks}

One of the volcano-plutonic zone features of Urmia-Dokhtar zone is injection of intrusive massed due to effect of the compression phase of late Eocene and early Oligocene in volcanic-sedimentary rows of Eocene. These infiltrators will cut 


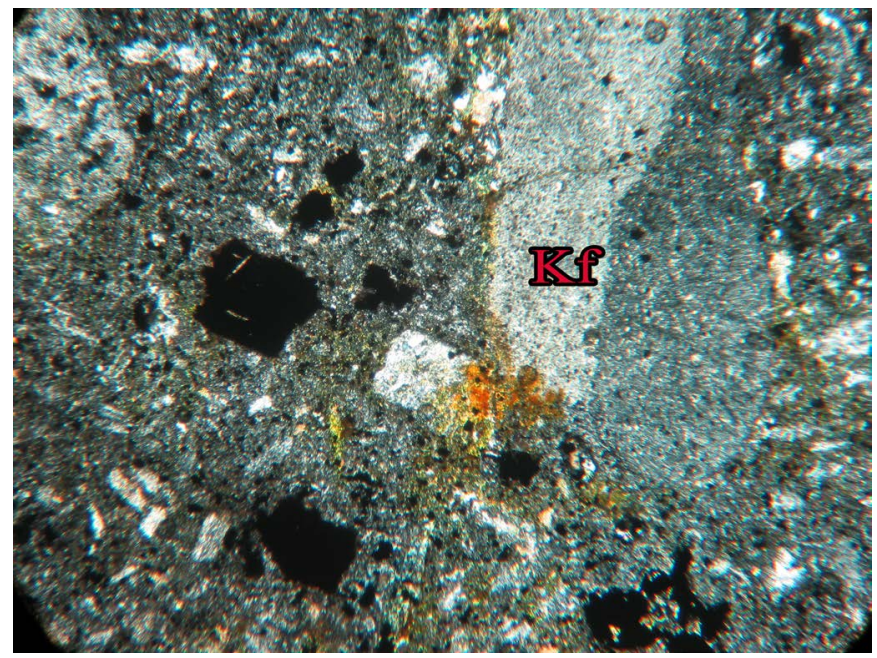

(a)

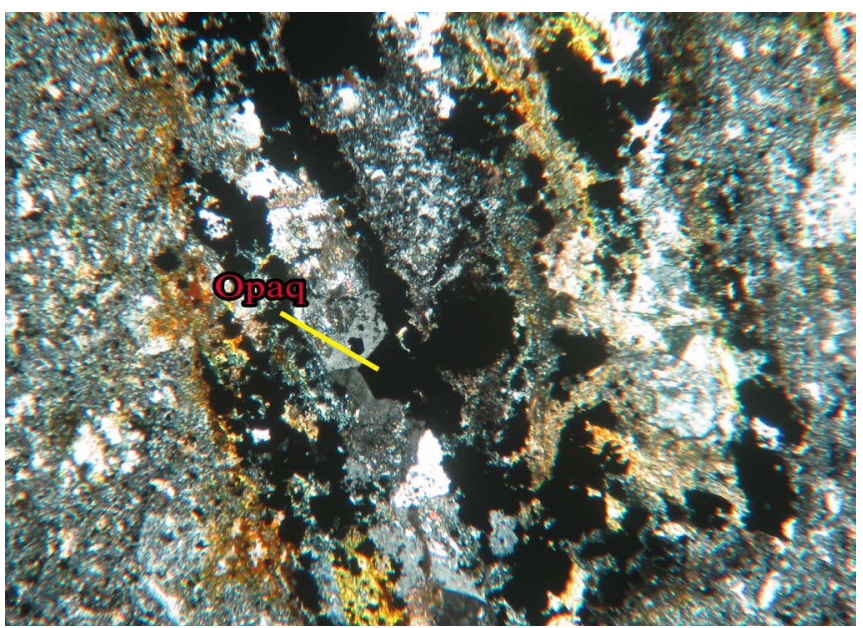

(b)

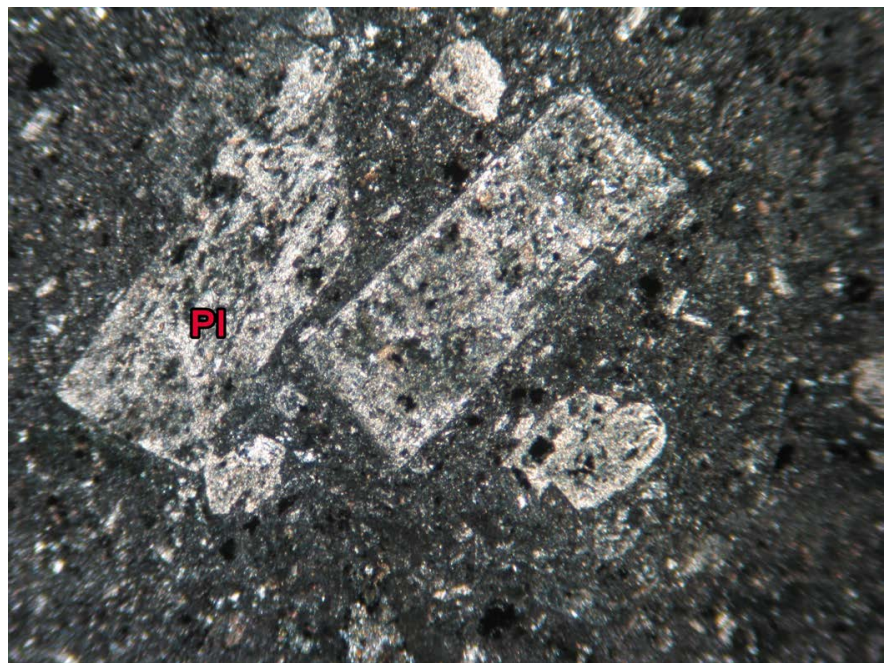

(c)

Figure 2. (a) a display of K-feldspar with Twining Carlsbad and rounded margin (b) and (c) The presence of opaque minerals, Plagioclase phenocrysts in a thin section and replacement of secondary quartz minerals and opaque in form of plagioclase. (a) XPL-6.3 * $10 \times$; (b) XPL-6.3* 10×; (c) XPL-6.3* $10 \times$. 


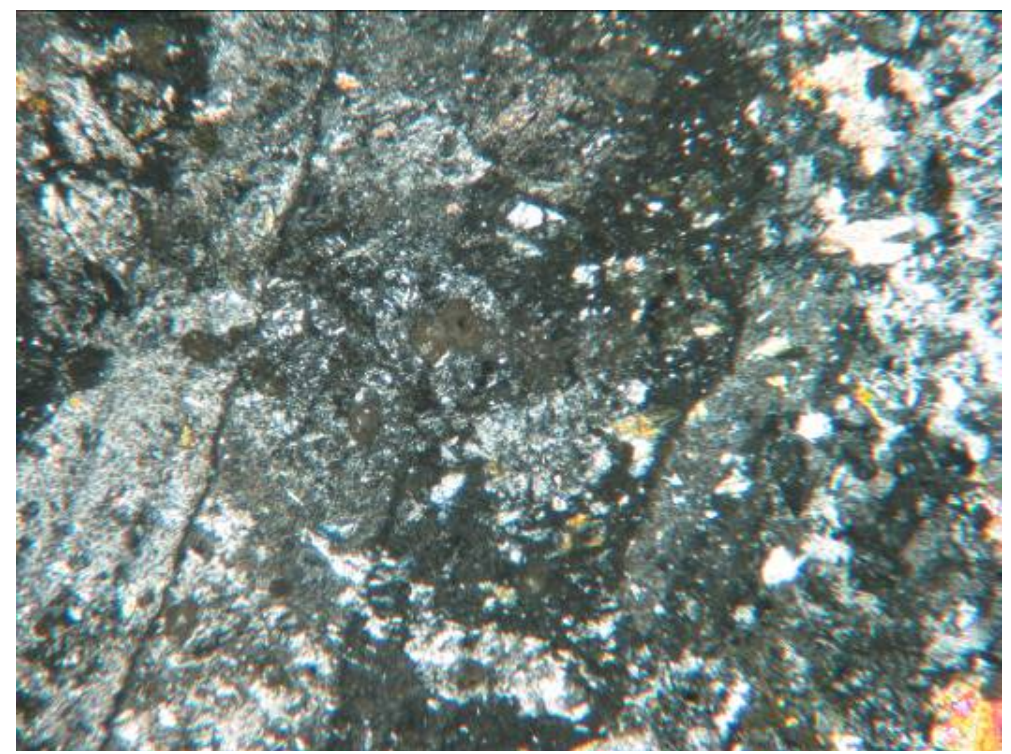

(a)

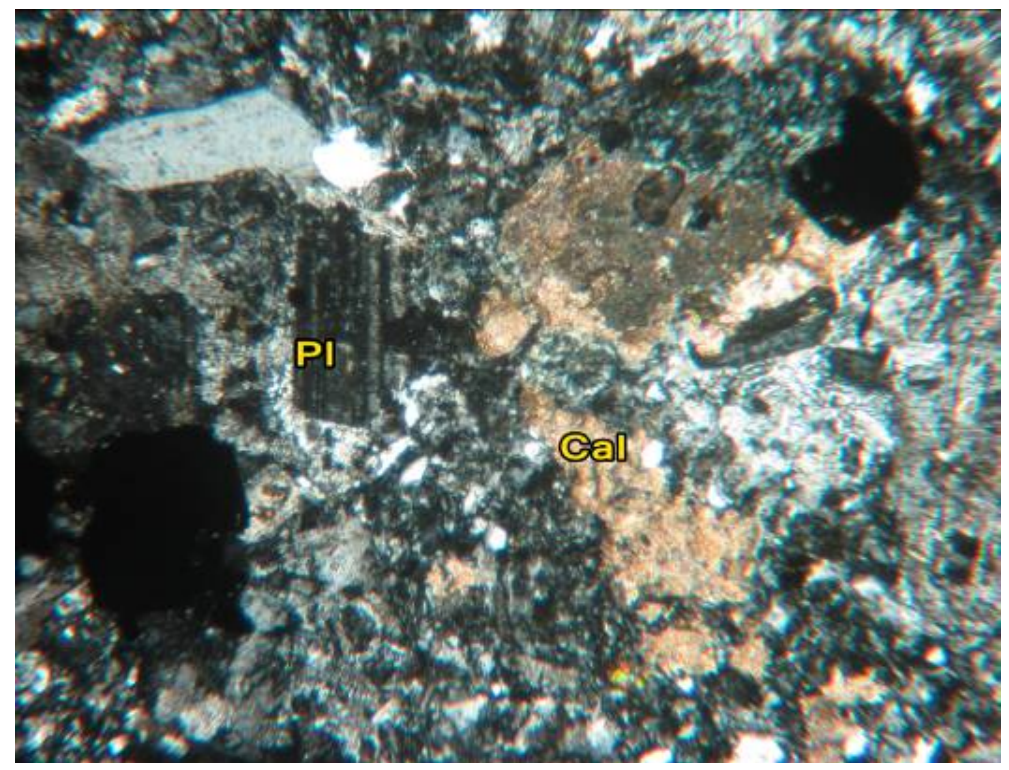

(b)

Figure 3. (a) and (b) Plagioclase with inclusions of the secondary minerals (epidote, calcite) and more alteration. (a) XPL- $6.3{ }^{\star} 10 \times$; (b) XPL- $6.3{ }^{\star} 10 \times$.

the stones of units related to Eocene and include diorite, monzonite, quartz monzonite, diorite, quartz with traces of ie aplite.

Its main minerals include plagioclase which has turned into alkali feldspar from the sides. Quartz crystals are amorphous to semi-shaped. Mafic minerals include amphibole, pyroxene and biotite. Secondary minerals include clay minerals Sericite, epidote, chlorite, calcium and apatite is present in some areas as minor minerals. Major texture of these stones is granular to granular-porphyritic and Sympathy Feldspar with quartz can be observed in Intergrowth granophyric to graphics (Figure 4).

Coarse crystals of altered feldspar (Sieve texture) to sericite and carbonate and 

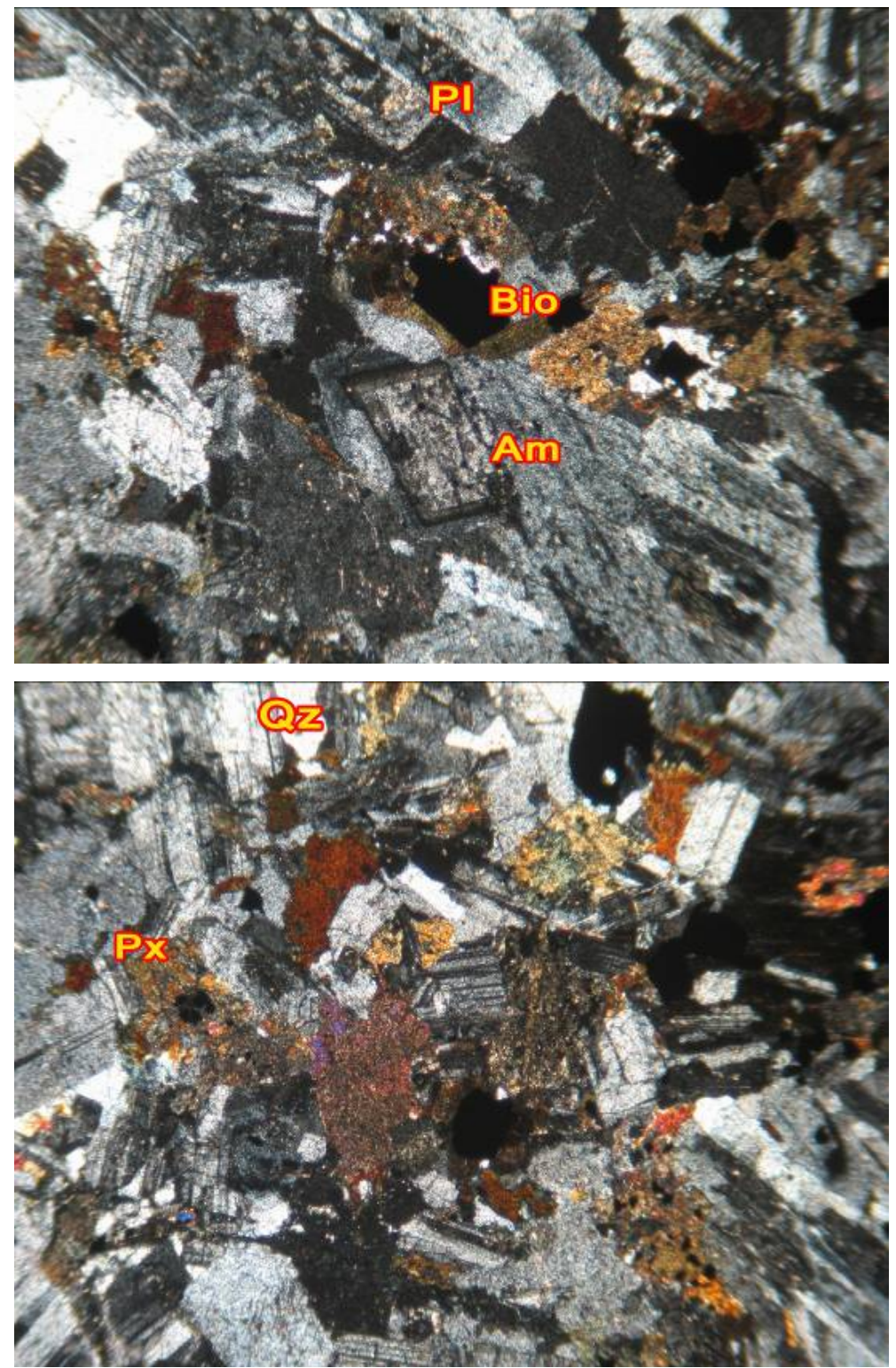

Figure 4. Crystalline granular texture in quartz diorite, including Mainly $\mathrm{Pl}, \mathrm{Px}, \mathrm{Am}, \mathrm{Bio}$, $\mathrm{Qz}$ and a small amount of $\mathrm{Kf}$ which have become somewhat argillic. Shaped and amorphous Fine and coars opaque mineral (Mainly iron oxide or Ti-Fe) are present more or less, Zoom is $(\times 10 \times 3.6-\mathrm{XPL})$

quartz crystals which present among them in amorphous and relatively abundant small and large forms have been shown in microscopic images (Figure 5) in a Quartz Monzonite rock.

Figure 6 shows the all crystalline texture of hegpidiomorphic type of monzodiorite rock in which the majority of forming crystals are half-shaped. There are shaped and amorphous crystals alongside them. Two types of alteration can be observed in this rock. We can observe both converting of plagioclase to carbonate and converting of biotite, amphibole and pyroxene to chlorite which means both carbonate alteration and chloritization are visible. Mafic minerals (Amphibole and pyroxene augite effects), Muscovite and muscovite biotite have 
appropriate presence. Opaque minerals are relatively abundant. Plagioclas has a significant presence with albite twinning and synthetic polymer. Most of which have been altered from the core (Normal zoning). There are veinlets in this rock which have been filled with secondary minerals (such as mica and Opaque). Amorphous quartz crystals can be seen among other minerals. Most of the Opaque crystals have been altered to ferric hydroxide. Effects of fine crystals chalcopyrite and pyrite are visible in rock.

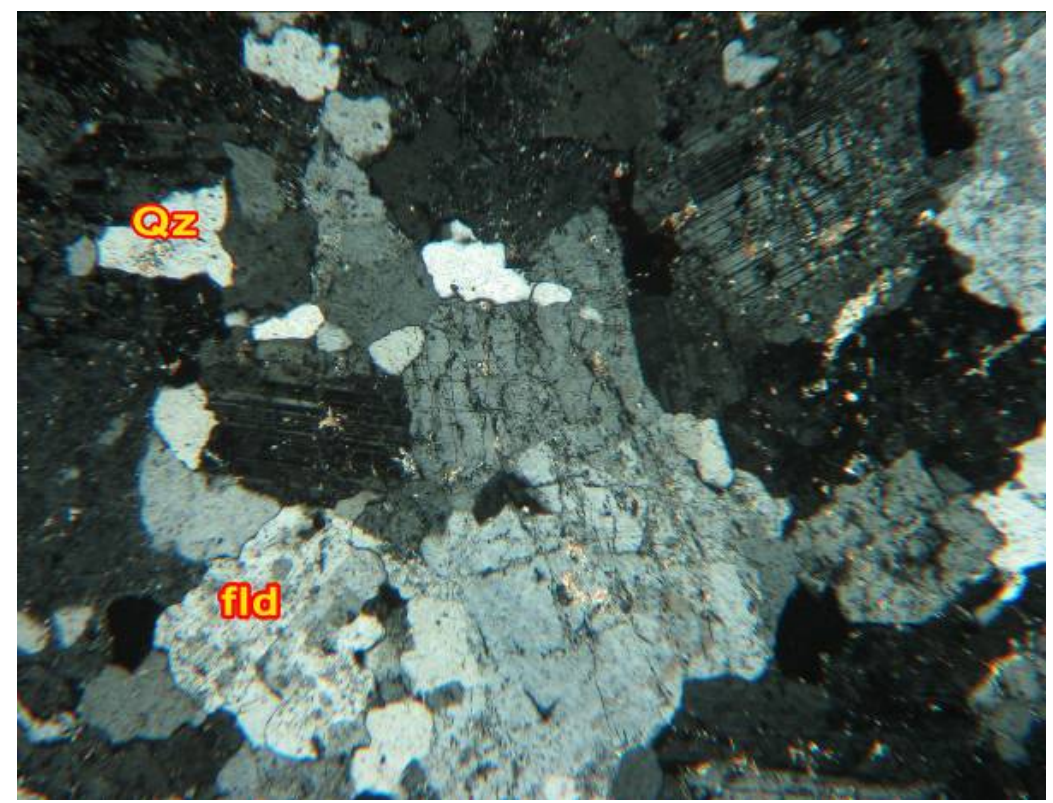

(a)

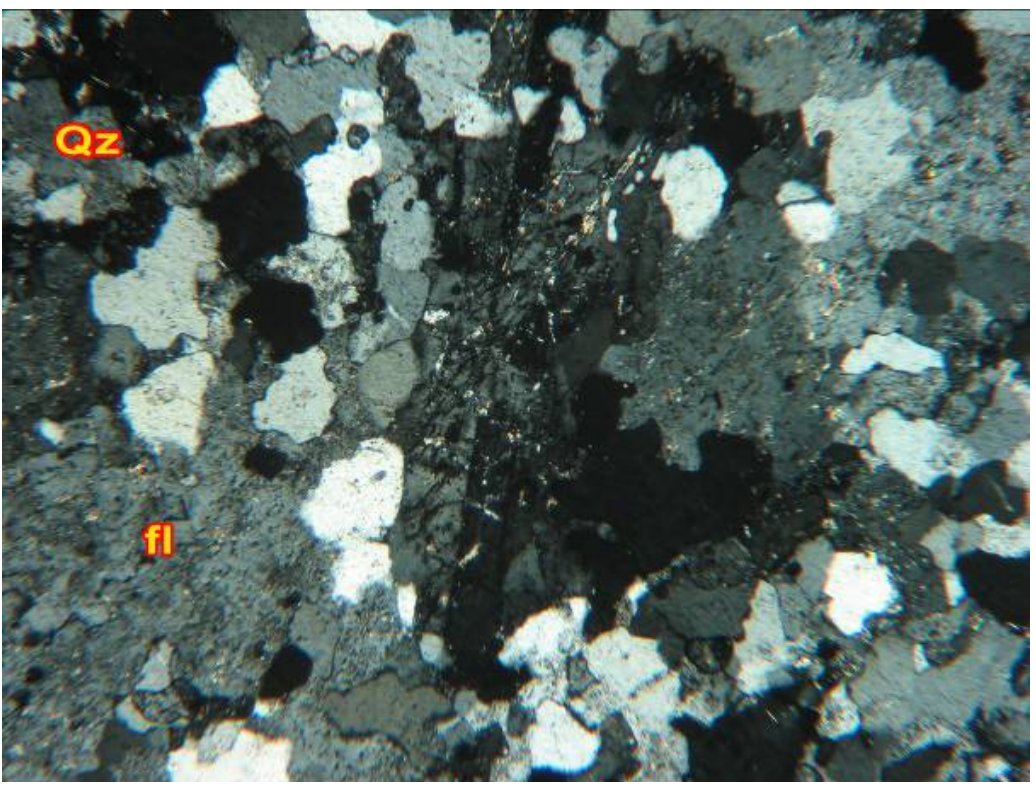

(b)

Figure 5. The sample of Quartz-feldspar in quartz monzonite stone A) Opaque minerals (coarse and fine) are present in the Rock B) It seems that a large part of quartz crystals are secondary and alteration product. There are joints in the rock which are filled with secondary crystals (epidote, mica, and calcite), Zoom is $(\times 10 \times 6.3-\mathrm{XPL})$. 


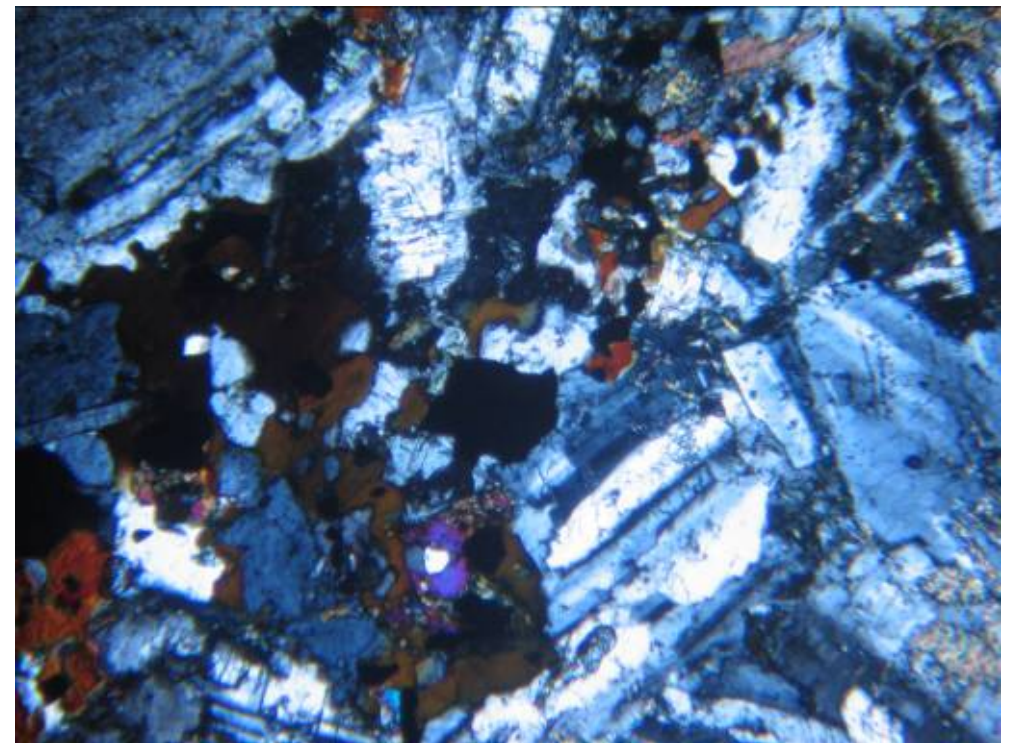

(b)

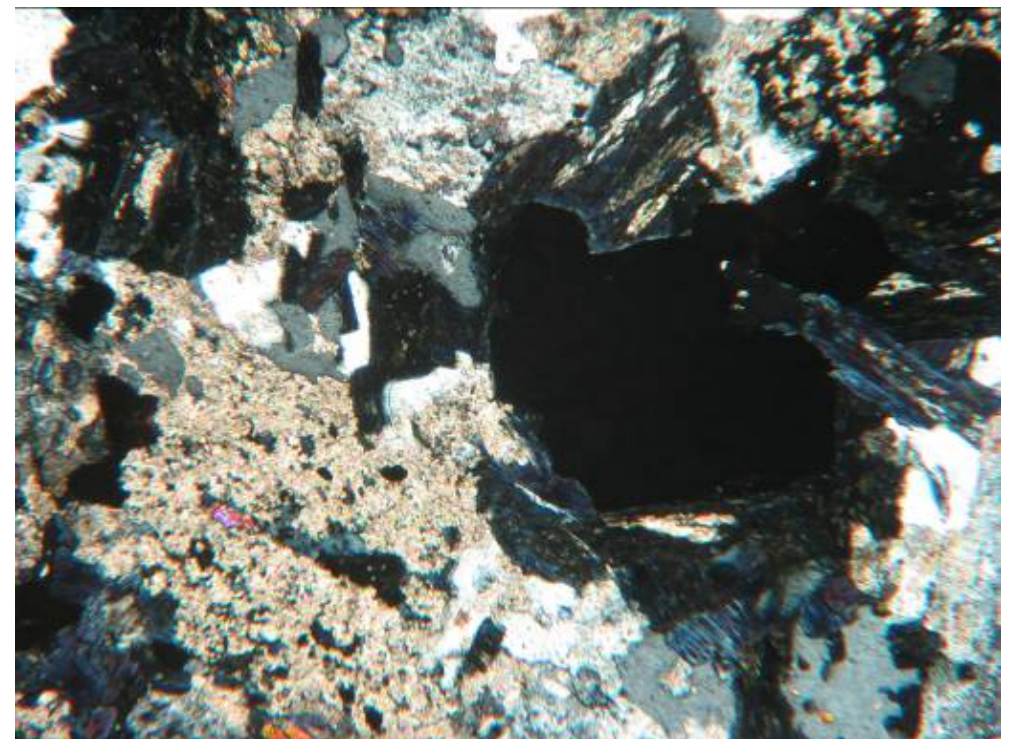

(b)

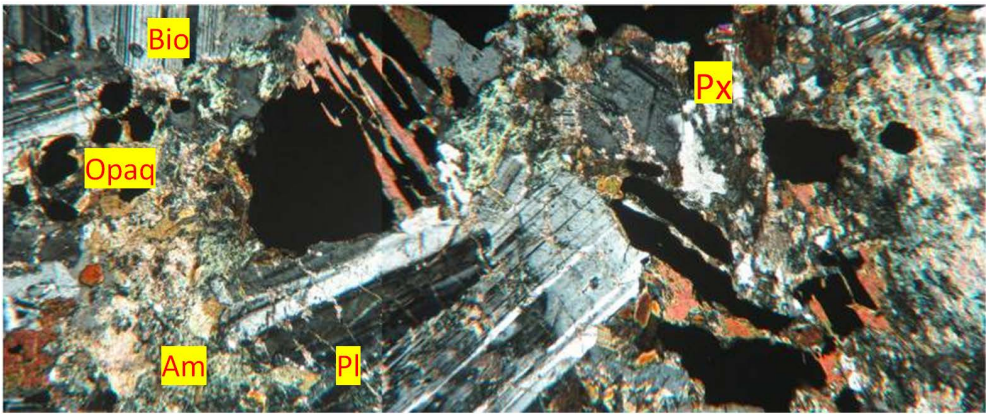

(c)

Figure 6. (a) Fully crystalline texture of hegpidiomorphic type, Zoom is $(\times 10 \times 6.3-$ XPL); (b) display of two types of alteration, both Carbonate alteration and chloritization, Zoom is $(\times 10 \times 6.3-\mathrm{XPL})$; (c) the presence of mafic minerals (Amphibole and pyroxene augite effects), Biotite and muscovite, chlorite and Opaque minerals are relatively abundant, Zoom is $(\times 10 \times 10-\mathrm{XPL})$. 


\subsection{Sulfide Mineralization}

Sulfide Mineralization in the studied area has been formed during hydrothermal reactions which has been located on the top of quartz monzonite intrusive in from of silica veins and veinlets and the highest concentrations of copper minerals can be observed in these veins. Further studies by XRF, SEM, and AAS analysis confirm the presence of $130.4 \mathrm{ppb}$ gold and $61 \mathrm{ppm}$ to $3 \%$ copper (Table 1 and Figure 14).

Since the studied are has created faults and fissures and fractures and subsequent sulfide mineralization as sulphide vein-veinlets Siliciclastic due to being located in a volcano-plutonic system and an active tectonic regime and according to field observations, Conditions governing the alteration systems, Results of Petrology and fluid inclusion studies, show the final stages of magmatic epithermal. Manual samples taken from Siliciclastic sulfide outcrops contain pyrite, chalcopyrite and malachite. Silicification-sulfide veins carrying mineralization, have outcrop in a length of 50 meters and a width of one meter and mainly with N75E/77SE trend (Figure 7).

Gold mineralization is outcropped in two ways:

A) Final Plutonism juices, in form of vein-veinlets and aplitic zones, carrying gold particles

B) Silicic-sulphide veins (with copper-gold)

After taking samples from these two outcrops series (Siliciclastic sulfide veins and aplitic zone) and carrying out XRF, SEM and AAS analyzes (Amir Kabir University and Tarbiat Modarres University) the presence of copper, gold and other associated and tracking elements such as silver, arsenic and mercury has been confirmed. The highest amount of gold in samples related to silicic sulfide veins is to the rate is of $112.2 \mathrm{ppb}$ and $130.4 \mathrm{ppb}$ and despite the fact that gold particles have been found in electron microscopic analysis related to aplitic samples, but it has not been reported in atomic absorption results. Of course, this can be related to factors such as low volume ( 0.8 grams) and lack of homogeneity of sample in preparation as a powder for the atomic absorption analysis. However, more samples for analysis for gold and associated elements are essential. The amount of copper has been reported to be from $61 \mathrm{ppm}$ to $3 \%$ in samples

Table 1. The results of the analysis of ores using EAAS method.

\begin{tabular}{cccccccc}
\hline Sample & $\mathrm{Cu}(\mathrm{ppm})$ & $\mathrm{Mo}(\mathrm{ppb})$ & $\mathrm{Cd}(\mathrm{ppb})$ & $\mathrm{As}(\mathrm{ppb})$ & $\mathrm{Au}(\mathrm{ppb})$ & $\mathrm{Ag}(\mathrm{ppb})$ & $\mathrm{Hg}(\mathrm{ppb})$ \\
\hline DY-1 & $>1 \%$ & 3940 & 76.8 & 2210 & 112.2 & 6070 & $<50$ \\
DY-8 & 8.66 & 424.2 & $<50$ & 431 & $<50$ & $<50$ & $<50$ \\
DY-10 & 53.06 & $<50$ & $<50$ & 299.8 & $<50$ & $<50$ & $<50$ \\
DY-12 & 13.22 & 246.9 & $<50$ & 126.8 & $<50$ & $<50$ & $<50$ \\
DY-14 & $>1 \%$ & 305.9 & $<50$ & 2190 & 130.4 & 5520 & 120.8 \\
DY-15 & 11.66 & 155.6 & $<50$ & 78 & $<50$ & $<50$ & $<50$ \\
DY-16 & 61.81 & 308.3 & $<50$ & 1280 & $<50$ & 451 & 87.7 \\
\hline
\end{tabular}




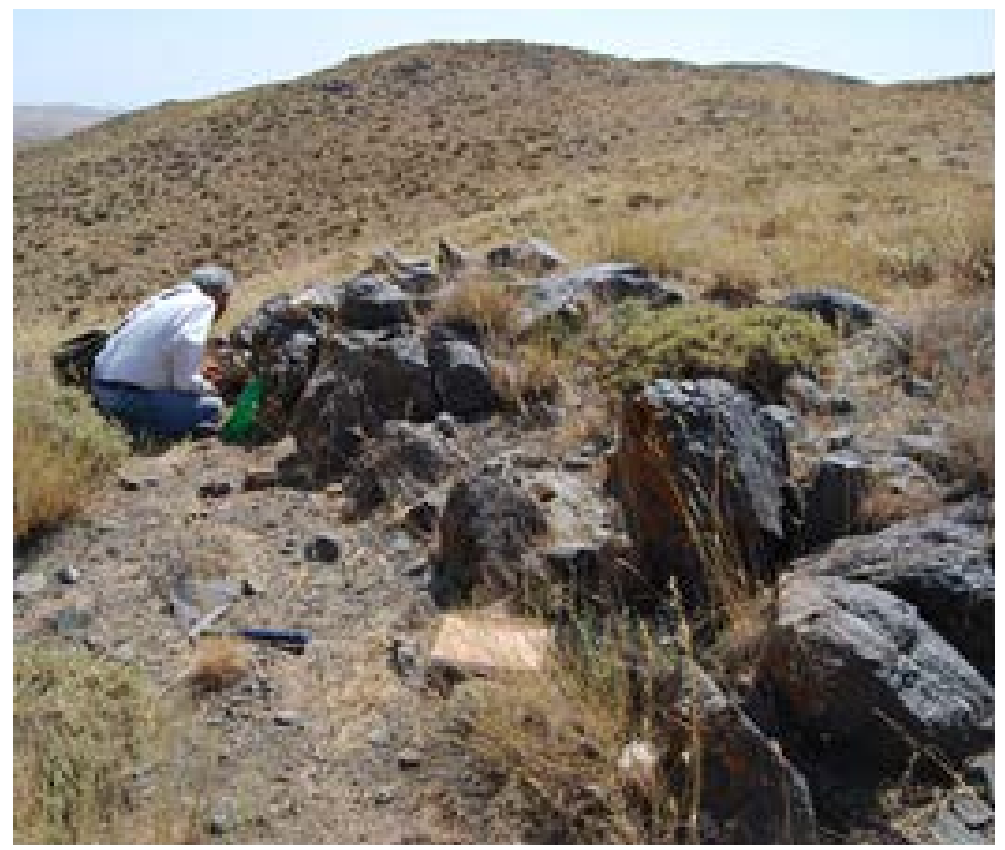

Figure 7. A display of siliceous sulfide vein.

related to silicic sulfide veins and from $13 \mathrm{ppm}$ to $53 \mathrm{ppm}$ in intrusive host rocks. The amount of silver of $0.45,5.5$ and $6 \mathrm{ppm}$ can only be observed in samples related to sulphide Siliciclastic veins. Molybdenum has been reported to be 1 to $5 \mathrm{ppm}$ in most samples. Arsenic is also present in samples related to veins from $1.2 \mathrm{ppm}$ to $2.2 \mathrm{ppm}$ (Table 1 ).

Due to observing the suspected presence of gold in microscopic sections as well as the results of atomic absorption analysis, we decided to select four samples of stones likely to have gold for electron microscopy. After electron microscopy studies (SEM/EDX) in Amirkabir University of Technology, as it can be observed in Figure 8, the presence of gold particles is confirmed. On the other hand, the presence of this precious metal in 5 stream sediment samples collected from the study area which was send and carried out for heavy mineral studies tothe Geological Survey, confirms the presence (Figure 8).

\section{Alteration}

Leakage of minerals is done along with alteration in many hydrothermal deposits, because as long as the hydrothermal fluids and host rock are in chemical equilibrium, minerals cannot be separated from them. This alteration which is related in time and place with mineralization is called Wall-Rock Hydrothermal alteration. Understanding the products and processes of alteration which are observed along with mineralization are the basis of identifying the processes related to genesis of the iron and lead to advances in exploration techniques [13].

Considering the importance of accurate recognition of alteration, information related to this section is based on studying satellite imagery, field observations, and microscopic studies of thin-polished sections and XRD analyzes. In the studies carried out using remote sensing (RS), in Figure 9 and subsequently the 


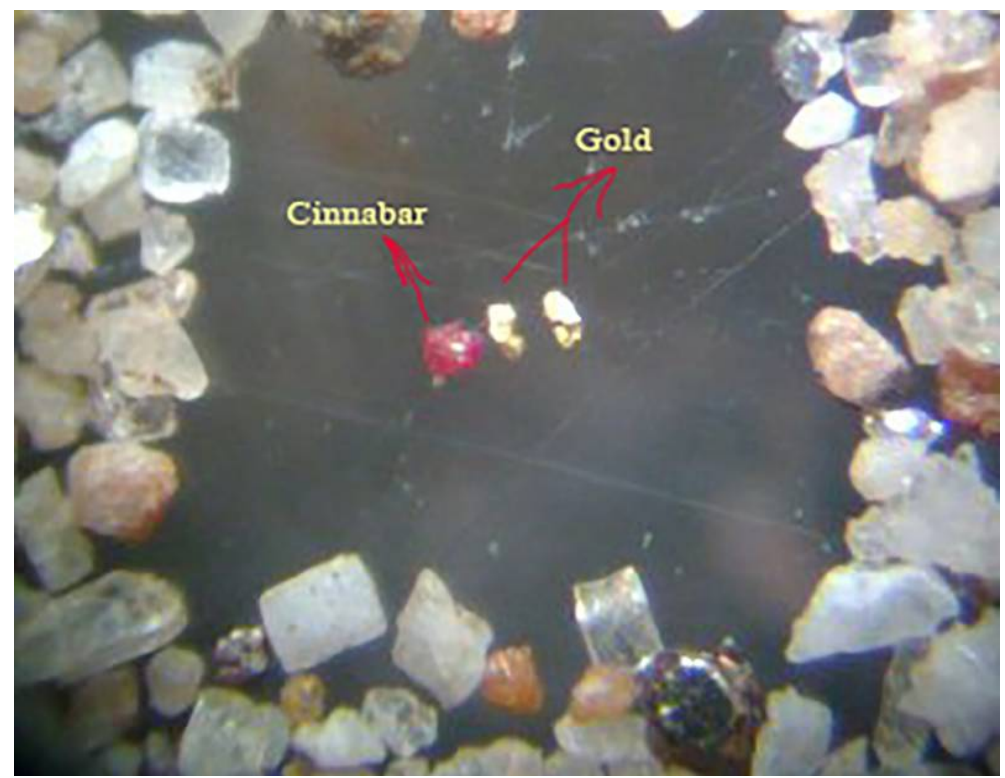

Figure 8. Gold particles and cinnabar in heavy mineral study have been shown in the middle of figure.

studied area, alteration zones and iron oxide can be drawn by placing different bands on each other. This has been done for argillic, kaolinite and iron oxide alterations which have been shown in Figure 9.

\subsection{Silica-Sulfide Alteration}

Mineralogy of quartz, amorphous silica, oxidized pyrite to iron oxides and hydroxides show Silica-sulfide alteration in many parts of the study area (Figure 10(a)). The presence of quartz mineral and dispersed particles of pyrite and iron oxides and jarosite can be seen.

Quartz can be seen in form of geode or Kukad in a structure and stretching area. Coarsely crystalline quartz has gradually become smaller from the core of geode to the periphery and is finally converted to background quartz. In fact, it is a kind of alteration in pores of the open space in which usually fabric forms upper parts of the epithermal systems (Figures 10(b)-(d)).

\subsection{Quartz-Sericite Alteration (Phyllic)}

This alteration is recognized with presence of quartz, pyrite and sericitic minerals which is also called the Phyllic alteration [14].

This type of alteration is one of the most frequent alterations in the study area. In a way that the presence of sericite is evident in most sections of stones. The primary stone is difficult to detect in some samples due to the intensity of becoming phyllic. Based on the results of XRD analysis and microscopic studies, minerals of this type of alteration include quartz, pyrite and sericitic. Adularia mineral has also been reported in some instances. Conversion of plagioclase, potassium feldspar and mafic minerals phenocrysts along the cleavages and from the edges and center of the sericite can be seen in different sections of rock units 


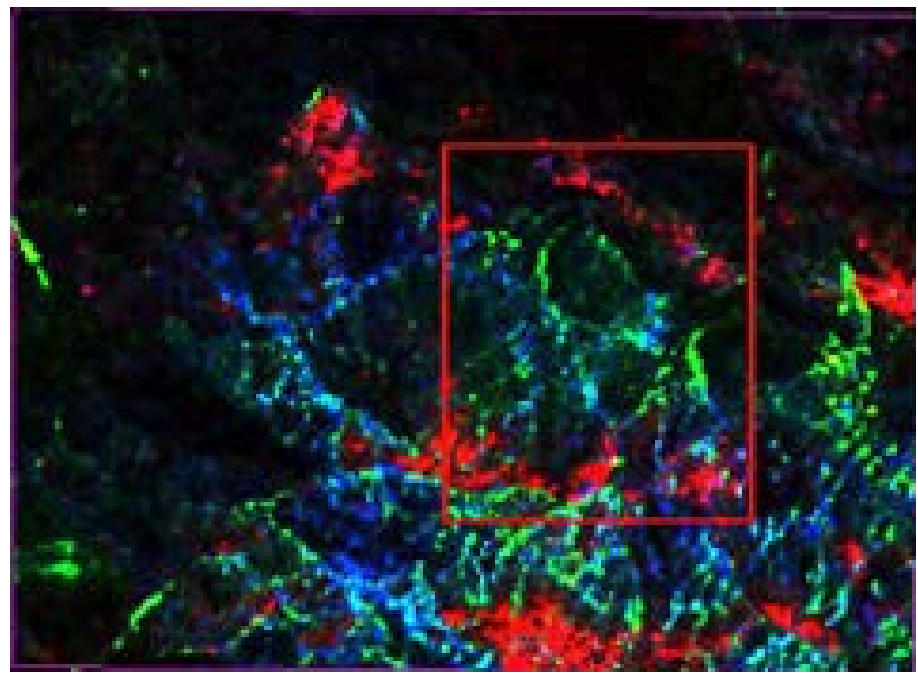

(a)

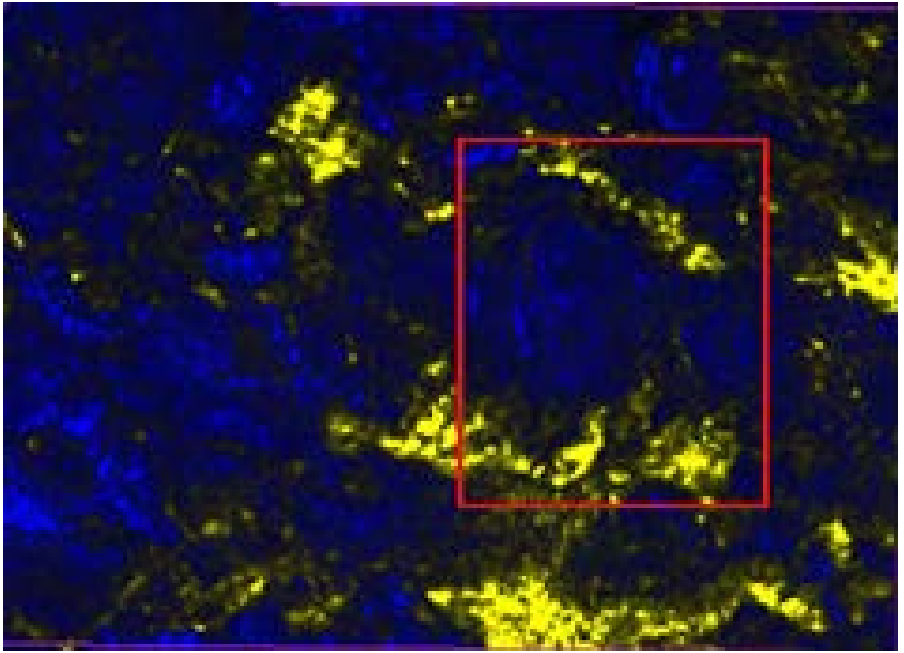

(b)

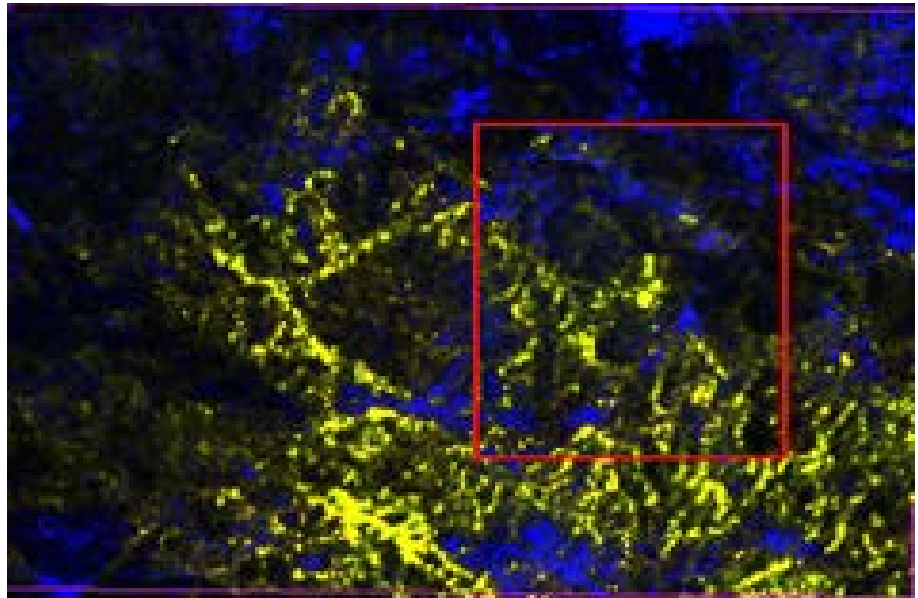

(c)

Figure 9. (a) A display of the extent of argillic alteration and iron oxide which has been determined in red; (b) a display of alteration zone which has been determined in yellow; (c) a display of the distribution of iron oxide alteration which has been determined in yellow. 


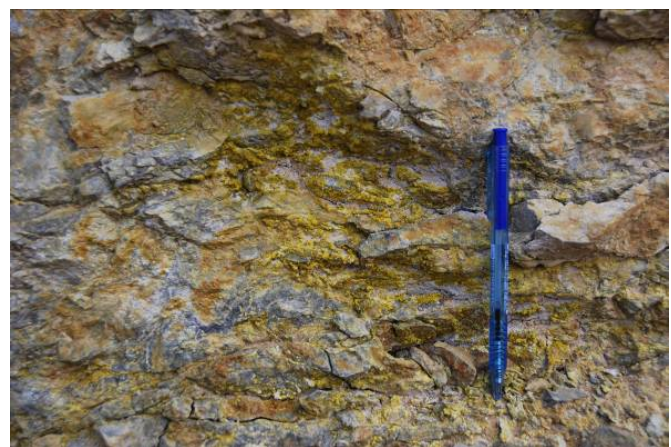

(a)

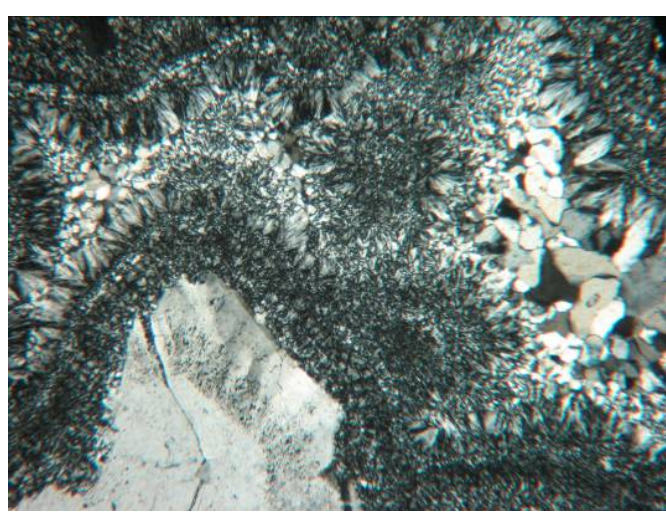

(b)

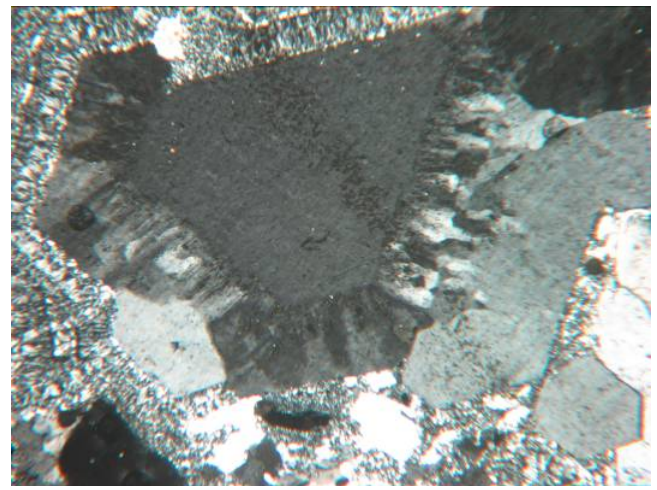

(c)

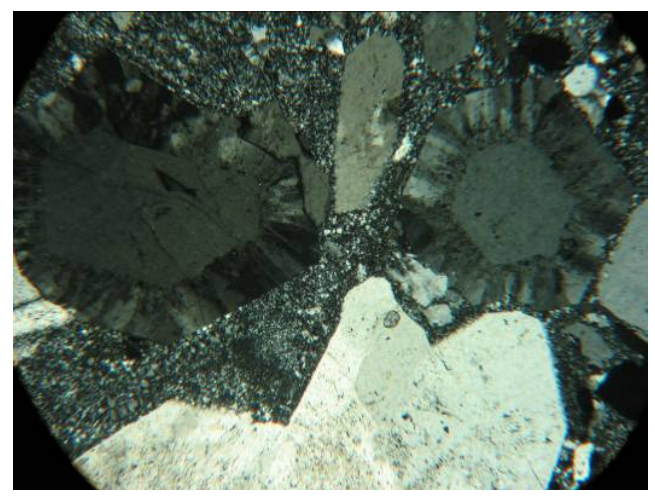

(d)

Figure 10. (a) Silica-sulfide alteration (b) until (c) a display of geodes or Kukads present in quartz which are the result of a type of alteration in open space pores in epithermal systems. 
which has sometimes led to complete decay of plagioclase and feldspar (Figure 11).

\subsection{Argillic Alteration (Moderate to Advanced)}

This alteration forms in supergene environments and due to the influence of atmospheric water and their downward movement through faults and fractures. These alterations contain minerals alunite, iron oxides, kaolinite and jarosite [15].

The presence of kaolinite, alunite, jarosite and iron hydroxides minerals in different parts of the study area (Figure 12) confirm the alteration type.

Thus, the presence of overlap of Phyllic-argillic alterations (moderate to high) and silicification are confirmed in this area based on conducted combined studies (Field studies, laboratory and remote sensing)

\subsection{Mineralogy and Paragenesis}

Studies and field observations and ore microscopic on thin-Polished and Polished sections as well as results of the analysis of XRD, SEM and heavy mineral, led to identification of minerals in area under study is as follows and shown in (Table 2).

Pyrite, chalcopyrite, gold, bornite, colitis, malachite and most important gangue minerals including quartz, calcite, adularia, albite, sericite, kaolinite, pyrophyllite, epidote, chlorite, alunite, jarosite and hydroxides of iron

Based on field observations, evaluation of manual samples, Microscopic studies, Structural and textural relations of mineralization stages of the study area, Minerals can be divided into three groups of Ortho-magmatic, the main stage of mineralization, the supergene and antioxidants in terms of genesis and formation process. Mineralization texture can mostly be observed in from of Veinlet vein as gap-space filler and succession and is present in aplitic zone of gold in

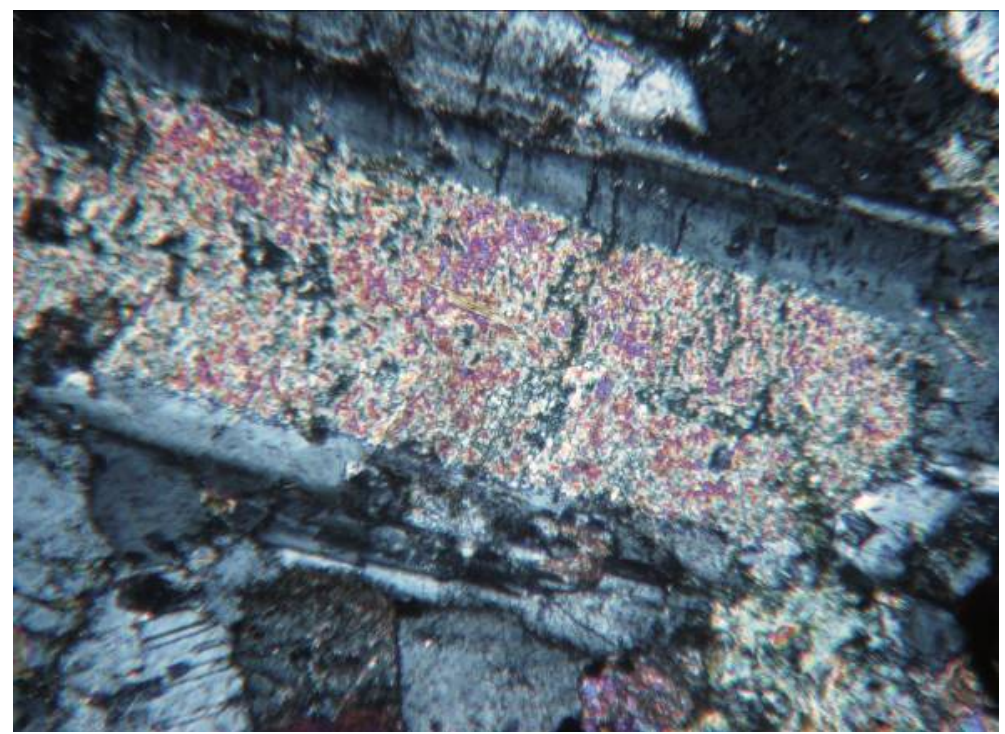

Figure 11. Plagioclase and feldspar. 


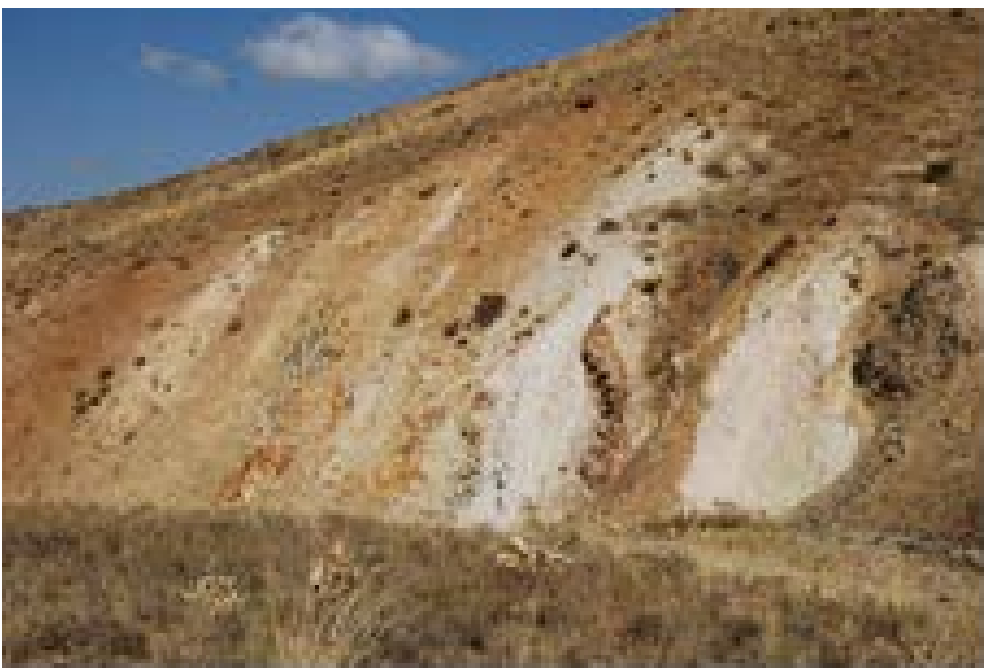

(a)

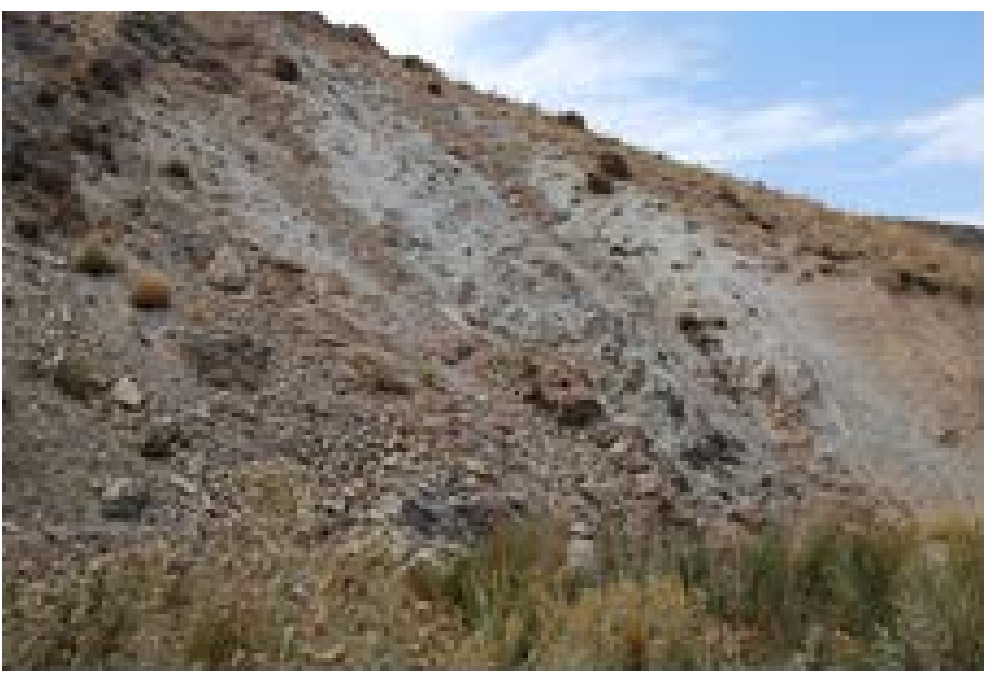

(b)

Figure 12. Images of argillic alteration in different parts of area and manual sample of altered host rock.

disseminated from. Gold mineralization is important in two stages of orthomagmatic and the main stage of mineralization. A closer examination of veinveinlets and aplitic zone containing the dimensions and thickness, and grade of gold is recommended.

\section{Ortho-Magmatic Stage}

According to information obtained from field studies and laboratory studies, minerals of this group are Rock-forming minerals and include quartz, feldspar, albite, pyroxene, hornblende and biotite. Magnetite and ilmenite minerals are present in the stones as minor minerals. Gold mineralization can be seen as disseminations in the last stages of Plutonism in vein-veinlets and aplitic zones which is confirmed and important according to microscopy and electron microscopy data (Figure 13). 
Table 2. Paragenetic sequence and crystallization of minerals in the study area.

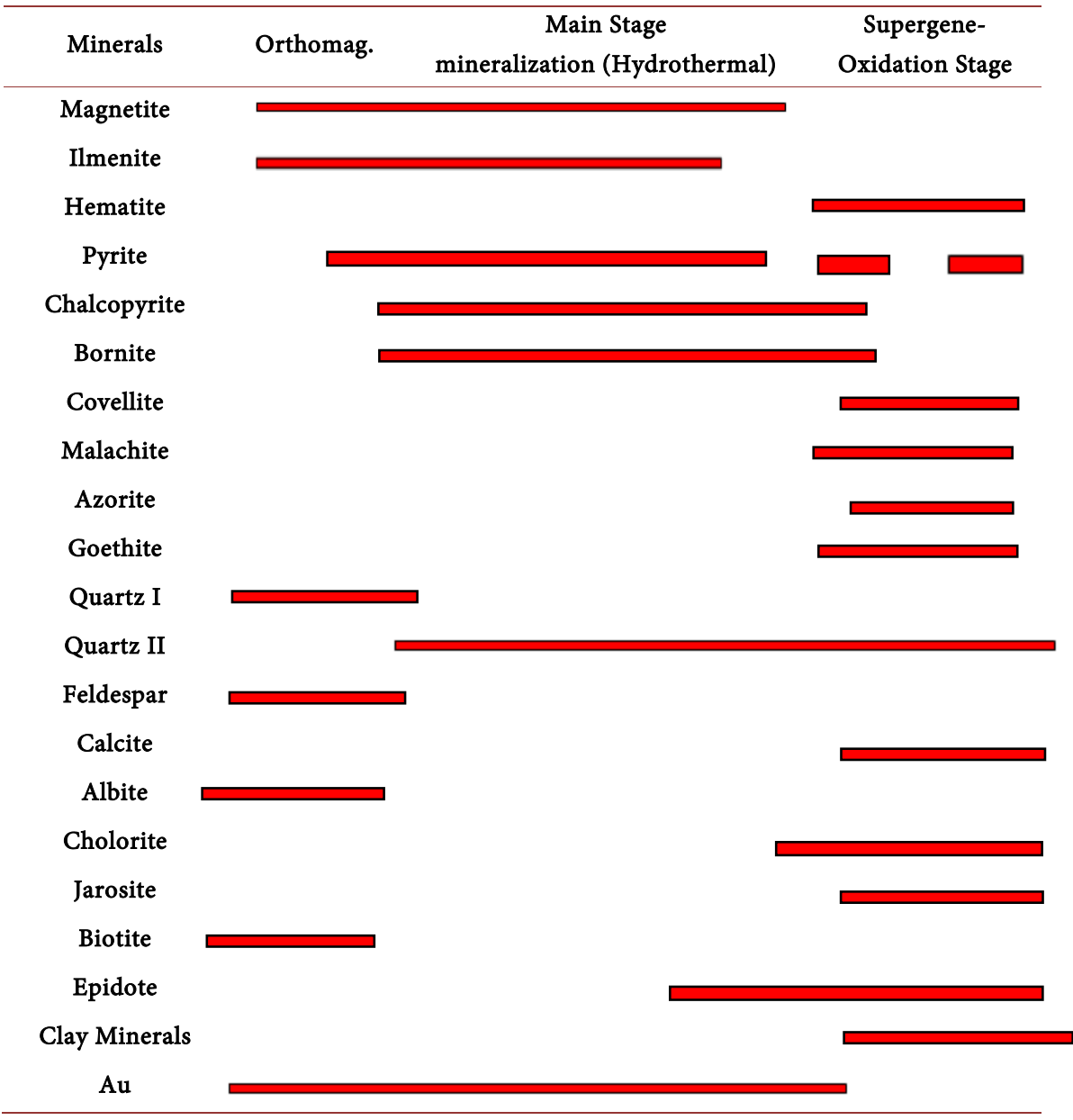

\section{The Main Mineralization Stage (Hydrothermal)}

Copper-gold mineralization has outcropped in sulfide vein-veinlets silicification in the study area. Minerals in this stage are iron hydroxides, the low level of ilmenite, pyrite, chalcopyrite, bornite, second-generation quartz and gold (Figure $14)$.

\section{Supergene and Weathering Stage}

Minerals formed in previous phases have converted to other minerals due to becoming unstable. Minerals of this stage are remaining pyrite, colitis, malachite, hematite, goethite, quartz, calcite, chlorite, Jarosite, epidote and clay minerals.

\section{Fluid inclusion Studies}

Sampling is one of the important factors considered in fluid inclusion studies, samples have been taken from quartz veins which have been obtained from of final Silica juices of a Plutonium system to joints and fractures of the area. Quartz veins are in the vicinity and top of intrusive and semi-deep rocks and metal mineralization can be seen in these veins (Figure 15). 


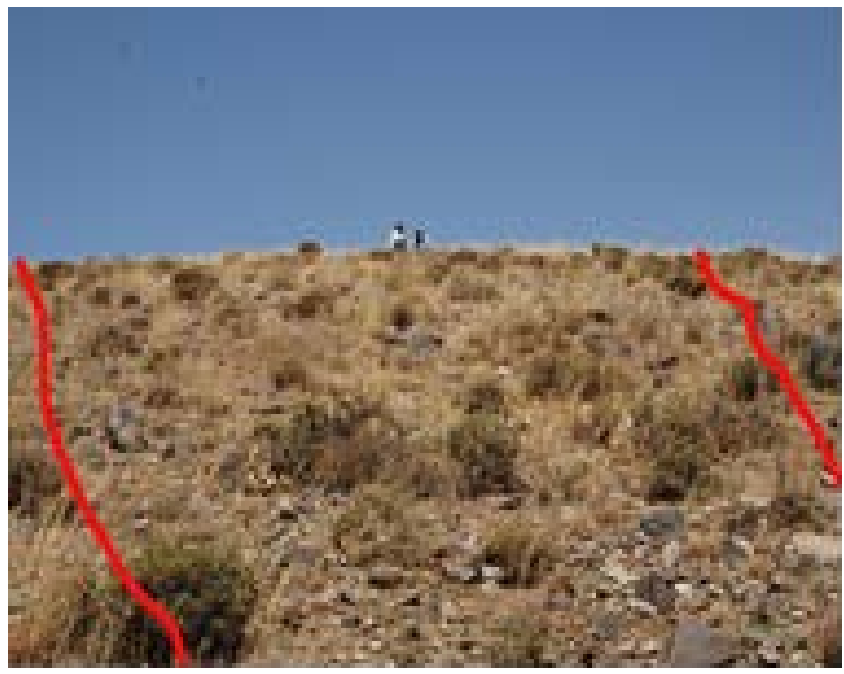

(a)

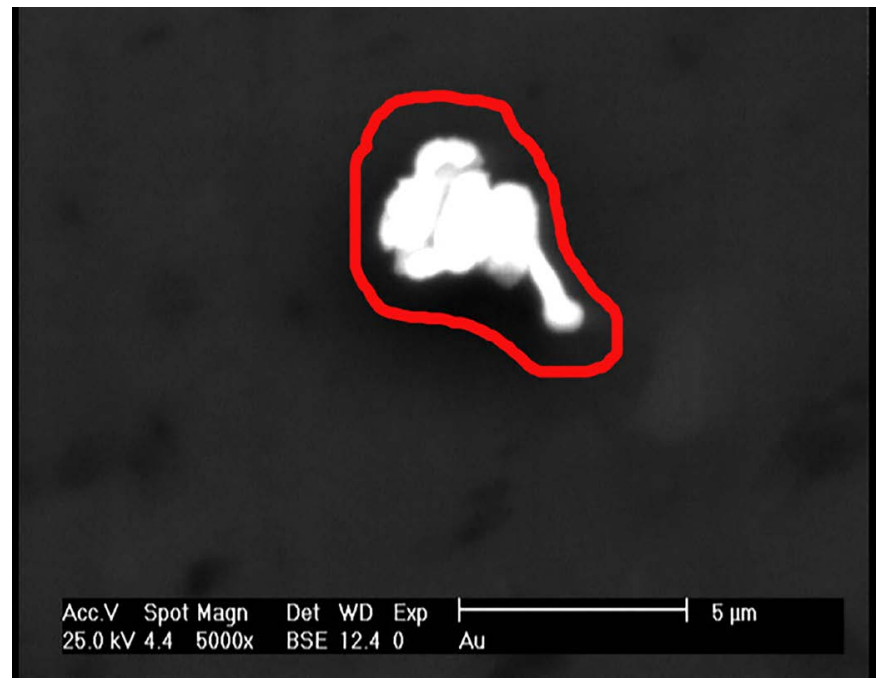

(b)

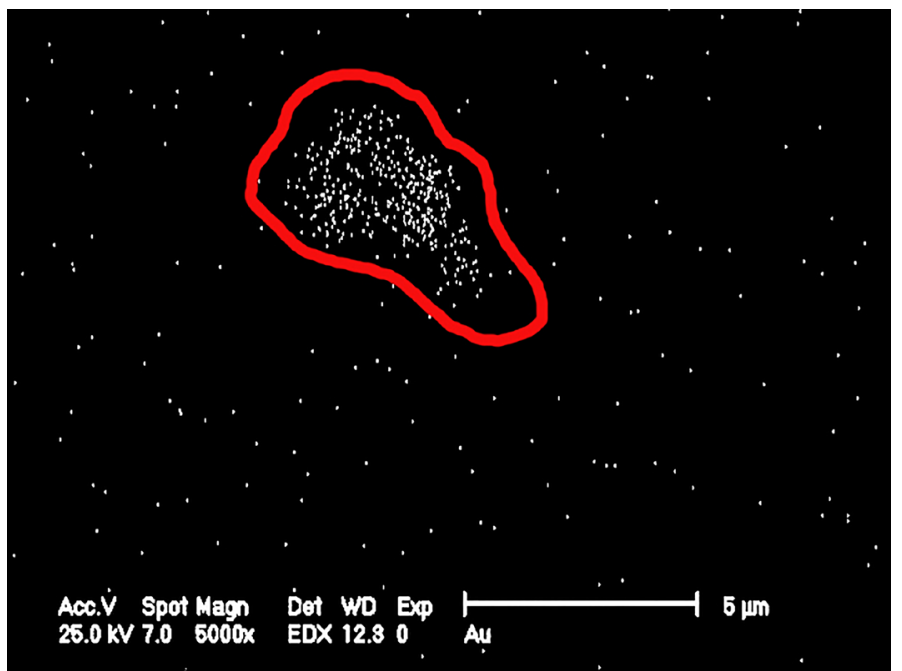

(c)

Figure 13. (a) Show of aplitic zone containing gold mineralization (b) and (c) show of (SEM) scan of aplitic rock's cross section and gold particles in it. 


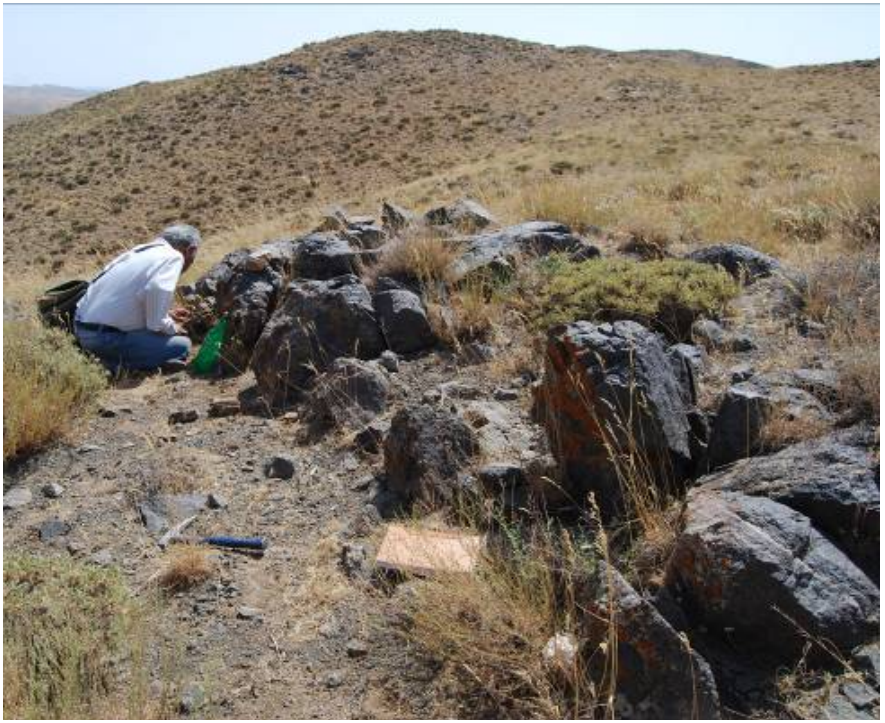

(a)

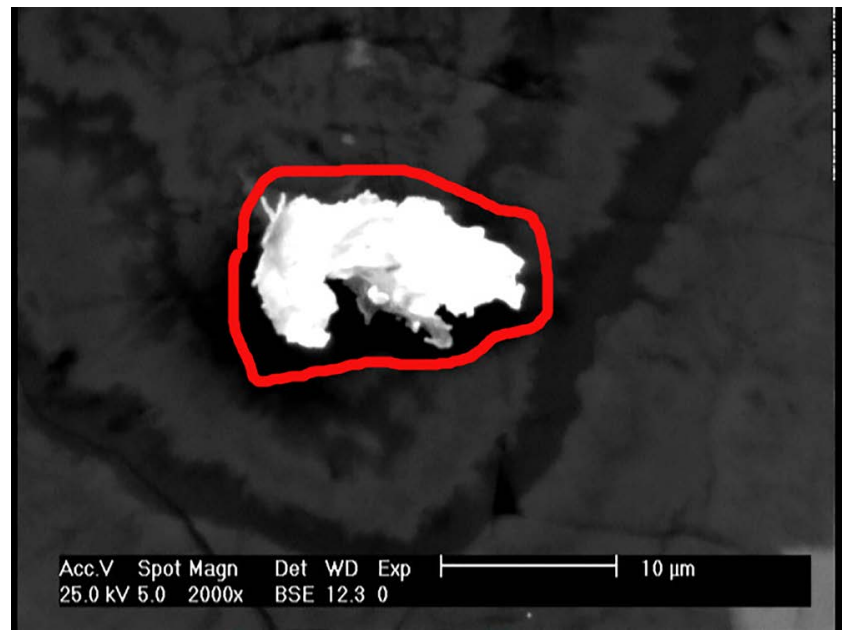

(b)

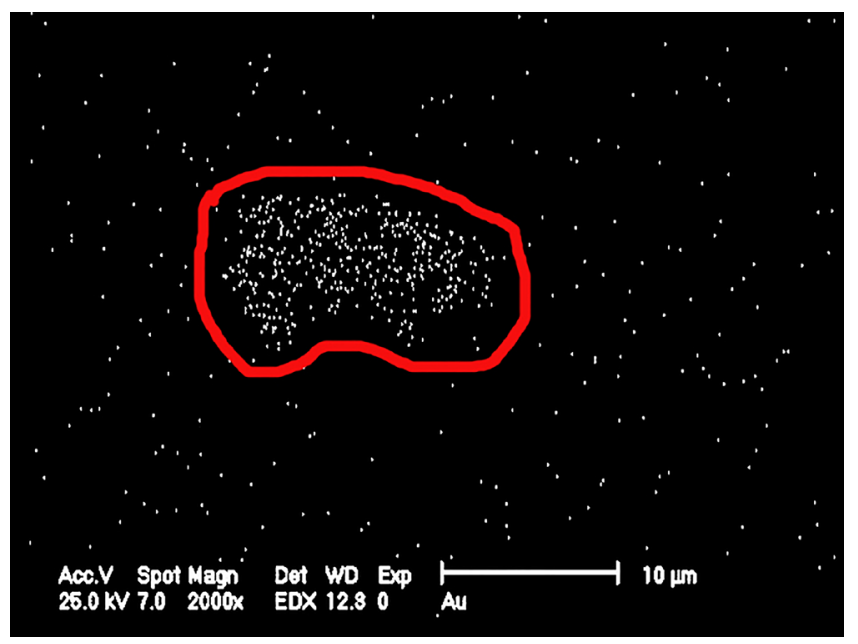

(c)

Figure 14. (a) A display of Silica veins containing copper-gold mineralization (b) and (c) a display of (SEM) scan of Silica sulfide vein's cross section and presence of gold particles in it. 
In sections of two selected samples, measurement especially measuring the levels of salt in them very difficult and impossible in some of them due to having small fluid inclusions (Figure 16). However, according to measurements carried out at primary fluid inclusions (all are two-phased, liquid and gaseous) on two selected samples of the quartz Gangue in silica vein carrying copper mineralization, values and figures related to homogenization temperature $\left(140^{\circ} \mathrm{C}\right.$ to $\left.306^{\circ} \mathrm{C}\right)$ and the degree of salinity (4 to 5.5 weight percent of salt) suggest that Mineralization is related to an epithermal system (Table 3). These kinds of fluids can usually be associated with those deeper parts of porphyry copper. Given that the number of measurements to calculate the salinity is very limited, Temperature to salinity charting is not practically possible.

\section{Discussion and Conclusion}

Epithermal gold reserves can be found along with acidic pyroclastic rocks and intermediate of Tertiary calc-alkaline which have appeared in drought environments. Also, their tectonic location is mainly subduction zone belts and back-arc areas. In such environment, advanced argillic, sericitic, alunite, silica and propylitic alterations can be seen which usually show anomalies of copper and other metals (including gold) [16] (Figure 17).

Sillito (1993) divided epithermal precious metals deposits in two main groups: 1) High-sulphidation type or acid sulfate 2) Low-sulphidation type or Adulariasericite. These two types of deposits have characteristics which have been referred to in Table 3. Also, some of the characteristics are related to the studied area which can be considered as Intermediate Epithermal according to obtained field and laboratory studies and observations.

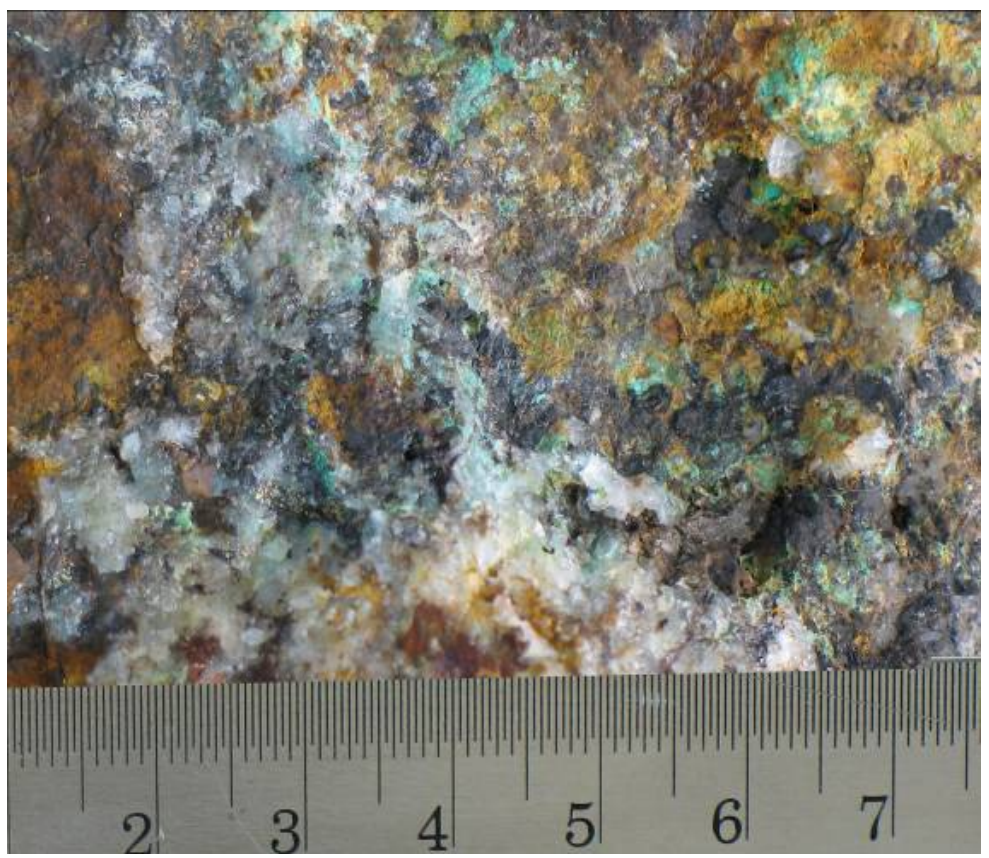

Figure 15. Manual sample of silica veins along with sulfides and oxides deposits. 

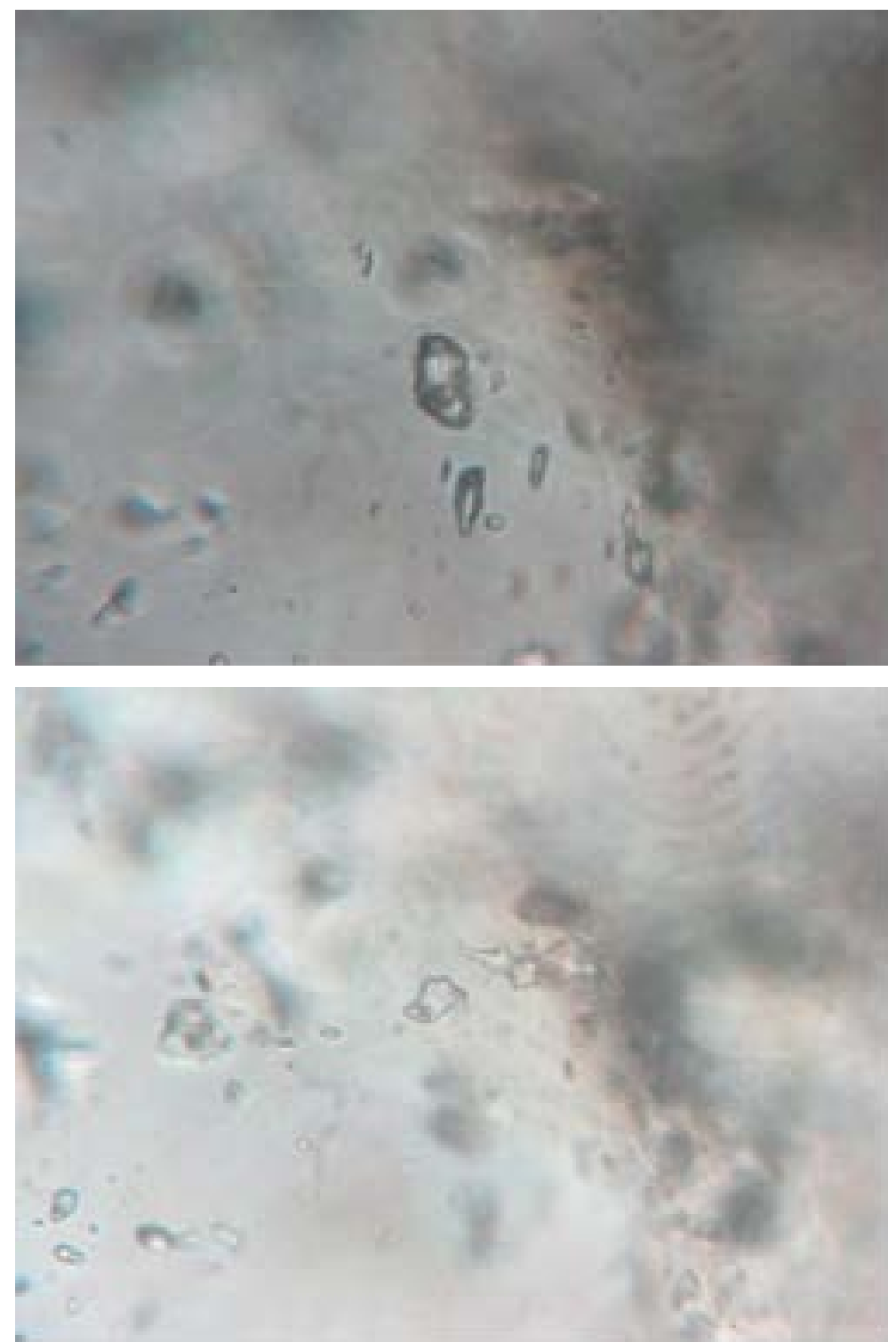

Figure 16. Fluid inclusions in quartz veins, zoom is $(\times 10 \times 80-\mathrm{XPL})$.

The extensive existence of argillic alteration (kaolinite) or alunite by considering other exploration parameters is a good guide to discover epithermal deposits [17]. Thus, considering the evidence obtained from the study area and the presence of kaolin mines in the $5 \mathrm{~km}$ of it, mineralization of the intended area can be considered as epithermal gold which has a more affinity with the kind of sulfuric acid.

Several Epithermal gold deposits and porphyry copper-gold can be named in Iran, most of which have structural and genetic similarities with the study area and most of them are located in Urmia-Dokhtar magmatic arc.

The data can be summed up in different angles according to a series of studies and field observations, microscopes, machine analysis and data processing using software and comparing them with known patterns.

In terms of tectonic environment, the study area is located in Urmia-Dokhtar 


\section{SUBDUCTION}

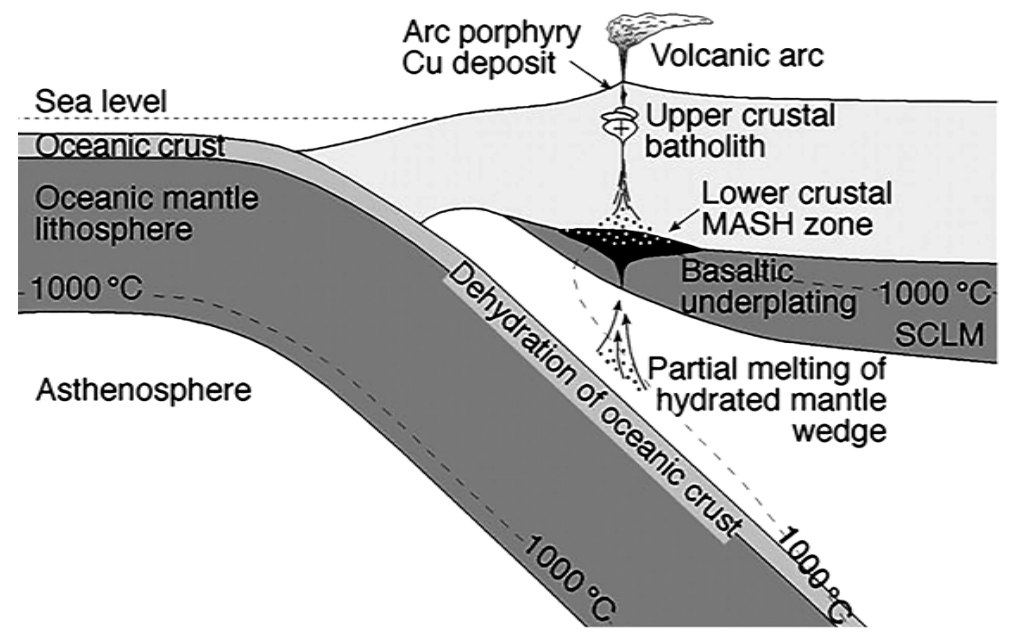

Figure 17. Subduction zone.

zone and is related to tectonic environment of volcanic arcs (VAG) of "Subduction magmatism product".

It can be said about Magmatism and its relation with mineralization that the thing which is exposed in the study area as the rock units are volcanic rocks, Trachyandesite to andesitic as intrusions and medium depth masses' host with granodiorite composition, Monzonite to Ie aplite granite and granite. In general, Magmatic activity in the area dates back to the Cenozoic Era. Intrusives are most likely related to Oligomiocene according to the report of 100,000:1 Khiaraj map (Danesfahan) which has cut volcanic rocks related to the Eocene. Therefore, it seems that intrusive masses and related hydrothermal fluids have a fundamental role in epithermal copper-gold mineralization.

The presence sulfides minerals in two veins and veinlets and disseminated types were studied along with silicic sulphide, rgillic and propylitic (the host rocks and intrusions) and mineralogy alterations and alteration in the veins of the area and the similarity of their Homogenization temperature and salinity in thermometry studies of fluid inclusion can imply that Copper-gold mineralization in sulphide Siliciclastic veins is related to a fluid mineralization system and this hydrothermal fluid has controlled the epithermal developments of the area. The majority of mineralization is related to sulphide Siliciclastic veins and it has also been observed in the aplitic area in laboratory studies of Gold Mineralization which may be referred to for the first time in Iran. Being influenced by the fault zones in the host rock is evident in both types of mineralization because the host rocks does not have any inherent permeability and mineralization feature but this feature is given to the host rock by presence of fault zones and density of fractures and fracturing and secondary porosity in the host rock in which sulphide Siliciclastic veins are formed by passage of fluids through these spaces and channels.

In general, it can be said that mineralization along and after intrusion has 
Table 3. The table of characteristics of High-sulphidation type and Low-sulphidation type epithermal deposits as quoted by Silito (1993) which changes by Shahbpor (2001) and its comparison with the study area [19].

\begin{tabular}{|c|c|c|c|}
\hline & $\begin{array}{l}\text { High sulphidation or } \\
\text { Sulfuric acid (alunite) }\end{array}$ & $\begin{array}{l}\text { Low sulphidation or } \\
\text { Adularia-sericite }\end{array}$ & $\begin{array}{l}\text { The study area } \\
\text { (South of Takestan) }\end{array}$ \\
\hline Tectonic position & arc Islands and continental margins & $\begin{array}{l}\text { rich type of Sulfur in arc Islands } \\
\text { and continental margins and weak } \\
\text { type of Sulfur in traction conditions } \\
\text { in arcs as well as post-orogenic } \\
\text { nditions }\end{array}$ & $\begin{array}{l}\text { continental margins Continental } \\
\text { volcanic arc, Urmia- Dokhtar zone }\end{array}$ \\
\hline Volcanic stones & $\begin{array}{l}\text { Mainly andesite and } \\
\text { rhyodacite }\end{array}$ & Andesite, rhyodacite, rhyolite & Andesite, trachyandesite \\
\hline Alteration zones & With cross and clear expansion & With low and non-clear expansion & Low to moderate expansion \\
\hline The key alteration minerals & $\begin{array}{l}\text { crystallized Alunite on the surface and } \\
\text { pyrophyllite in the deep }\end{array}$ & $\begin{array}{l}\text { Cervisitis or illite + adularia, Rose } \\
\text { colitis in deposits associated with } \\
\text { alkaline stones and in some cases } \\
\text { chlorite }\end{array}$ & $\begin{array}{l}\text { Alunite in Argillic-alunite zone, } \\
\text { adularia has also been observed }\end{array}$ \\
\hline Quartz & $\begin{array}{l}\text { Fine and bulk, Fine and bulk, mainly with } \\
\text { succession origin }\end{array}$ & $\begin{array}{l}\text { Chalcedony or quartz with cortex } \\
\text { species, chloroform, blade, } \\
\text { Chasma Filling Kakadu }\end{array}$ & $\begin{array}{l}\text { Coarse and crystallized with Gulf } \\
\text { texture and Geodetic and Kakadu, } \\
\text { also in form of fine and substitution }\end{array}$ \\
\hline Other tailings & $\begin{array}{c}\text { Barite with great expansion which is } \\
\text { combined with mineral, Chasma filling } \\
\text { sulfur is present }\end{array}$ & $\begin{array}{c}\text { Barite of fluorite exists locally and } \\
\text { barite can be found at the top of } \\
\text { mineralized mass }\end{array}$ & Quartz, Sericitization, clay \\
\hline Sulfide minerals' values & $\begin{array}{c}10 \text { to } 90 \% \text { Volume percentage, mainly fine } \\
\text { and some form of pyrite layer }\end{array}$ & $\begin{array}{c}1 \text { to } 20 \% \text { Volume percentage, but } \\
\text { mainly less than } 5 \% \text { Volume } \\
\text { percentage, pyrite }\end{array}$ & $\begin{array}{c}4 \text { to } 6 \% \text { Volume percentage, mainly } \\
\text { pyrite }\end{array}$ \\
\hline The key sulfide minerals & $\begin{array}{l}\text { copper Sulphosalts (Enargite) and copper } \\
\text { and copper-iron sulfides } \\
\text { (chalcocite, covellite, bornite) are common } \\
\text { and are formed after pyrite }\end{array}$ & $\begin{array}{l}\text { Sphalerite, galena and tetrahedrite } \\
\text { are common. Copper is present } \\
\text { mainly as chalcopyrite. }\end{array}$ & $\begin{array}{l}\text { Copper, mainly as chalcopyrite } \\
\text { and colitis along with pyrite }\end{array}$ \\
\hline Existing metals & $\mathrm{Cu}, \mathrm{Au}, \mathrm{As}(\mathrm{Ag}, \mathrm{Pb})$ & $\mathrm{Au}$ or $\mathrm{Ag}(\mathrm{Cu}, \mathrm{Pb}, \mathrm{Zn})$ & $\mathrm{Cu}, \mathrm{Fe}, \mathrm{Au}, \mathrm{Ag}, \mathrm{Mo}$ \\
\hline Metals that are topical & BI, SB, Mo, Sn, Zn, Te(Hg) & $\mathrm{Sb}, \mathrm{As}(\mathrm{Te}, \mathrm{Se}, \mathrm{Hg})$ & $\mathrm{Hg}, \mathrm{AS}$ \\
\hline $\begin{array}{l}\text { The ratio of sulfur to metal } \\
\text { in sulfide minerals }\end{array}$ & up & down & up \\
\hline $\begin{array}{l}\text { Nature of the fluid deposit } \\
\text { mechanism }\end{array}$ & Acidic, rich in sulfur and oxides & Neutral, pitch of sulfur and redox & Acidic, rich in sulfur and oxides \\
\hline $\begin{array}{l}\text { The source of fluid deposit } \\
\text { mechanism }\end{array}$ & Mainly with magmatic fluid & Mainly containing meteoric water & $\begin{array}{l}\text { ainly magmatic hydrothermal } \\
\text { fluids and meteoric fluids }\end{array}$ \\
\hline $\begin{array}{l}\text { Association with porphyry } \\
\text { deposits }\end{array}$ & $\begin{array}{l}\text { Gold deposits have been formed in upper } \\
\text { parts of copper-gold deposits and } \\
\text { porphyry copper molybdenum and } \\
\text { simultaneously with these deposits } \\
\text { (West Pacific arc islands, Philippines and } \\
\text { Central Andes, Chile) }\end{array}$ & $\begin{array}{l}\text { Gold deposits around porphyry } \\
\text { copper deposits in the Philippines }\end{array}$ & $\begin{array}{l}\text { Gold mineralization associated with } \\
\text { copper in the upper part and the } \\
\text { possible presence of porphyry } \\
\text { copper in below and greater depths }\end{array}$ \\
\hline
\end{tabular}

been formed due to the release of magmatic fluids and in system terminals with the involvement of meteoric fluids and are controllers in many parts of the tectonic structures. This set can be considered to be Intrusion Related which is usually observed along with hydrothermal copper-gold mineralization [15] [18]. Data collection of the present research such as geodynamic environment, geology (volcano-plutonic complex), zones of alteration and mineralization in the 
upper part of the mentioned complex can be indicative of the fact that this mineralization may be related to a porphyry copper-gold system in deep.

\section{References}

[1] Sillitoe, R.H. and Hedenquist, J.W. (2003) Linkages between Volcanotec-Tonic Settings, Ore-Fluid Compositions, and Epithermal Precious Metal Deposits. Society of Economic Geologists Special Publications, No. 10, 315-343.

[2] Ringwood, A.E. (1977) Petrogenesis in Island Arc Systems. In: Talwani, M. and Pitman, W.C., Eds., Island Arcs, Deep Sea Trenches, and Back Arc Basins: American Geophysical Union Maurice Ewing Series I, 311-324. https://doi.org/10.1029/ME001p0311

[3] Candela, P.A. (1992) Controls on Ore Metal Ratios in Granite-Related Ore Systems: An Experimental and Computational Approach. Royal Society of Edinburgh Transactions, Earth Sciences, 83, 317-326.

[4] Richards, J.P. (2005) Cumulative Factors in the Generation of Giant Calc-Alkaline Porphyry Cu Deposits. In: Porter, T.M., Ed., Super Porphyry Copper and Gold Deposits: A Global Perspective, Volume 1, Porter Geoscience Consulting Publishing, Linden Park, South Australia, 259-274.

[5] Candela, P.A. and Holland, H.D. (1984) The Partitioning of Copper and Molybdenum between Silicate Melts and Aqueous Fluids. Geochimica et Cosmochimica Acta, 48, 373-380. https://doi.org/10.1016/0016-7037(84)90257-6

[6] Johnson, R.W., Mackenzie, D.E. and Smith, I.E.M. (1978) Delayed Partial Melting of Subduction-Modified Mantle in Papua New Guinea. Tectonophysics, 46, 197 216. https://doi.org/10.1016/0040-1951(78)90114-2

[7] Sillito, R.H. (1993) Epitermal Models: Genetic Type, Geometrical Controls and Shallow Features. In: Kirkham, R.V., Sinclair, W.D., Thorpe, R.I. and Duke, J.M., Eds., Minera Deposit Modeling, Geol Assoc., Can Spec pap 40, 403-417.

[8] Karimpour, M.H., Malek Zadeh, A. and Heydariyan, M.R. (2002) Exploration of Mineral Resources, the Geology, Geochemistry, Satellite and Geophysics. Ferdowsi University of Mashhad, p. 636.

[9] Eghlimi, B. and Mosavari, F. (2000) A Geological Map of 1:100,000 Khiaraj (Danesfahan), Geological Survey of Iran. Bank of Mines Information, Geosciences Database of Iran.

[10] Stocklin, G. (1968) Structural History and Tectonic of Iran: A Review. American Association of Petroleum Geologists Bulletin, 52, 1229-1258.

[11] Nogol Sadat, M.A.A. (1985) Regional Structural Shear and Bending in Iran. Structural Analysis of the Achievements of Qom, Report No. 55, Geological Survey of Iran.

[12] Aghanabati, A. (2006) Iran Geology, Geological Survey of Iran, p. 586.

[13] Lentz, D.R. (1994) Alteration and Alteration Processes Associated with Ore-Forming System. Geological Association of Canada Short Course Notes, 11, 16-22.

[14] Pirajno, F. (2009) Hydrothermal Mineral Deposits, Principles and Fundamental Concepts for the Exploration Geologist. 1992 Edition, Springer, p. 706.

[15] Hedenquist, J. (1992, 2000) Mineralization of Volcanogenic Hydrothermal Systems in the Circum Pacific and their Reconaition, Epithermal Gold in Asia and Pacific. 19-22.

[16] Hedenquist, J.W. and Henely, R.W. (1985) Hydrothermal Eruption in the Waitapu Geothermal System, New Zealand: Their Origin, Associated Breccias, and Relation to Precious Metal Mineralization. Economic Geology, 80, 1640-1668. https://doi.org/10.2113/gsecongeo.80.6.1640 
[17] Karimpour, M.H. and Saadat, S. (2005) Geology Applied Economics. Ardalan Press, Tehran, p. 535.

[18] Cox, D.P. and Singer, D.A. (1986) Mineral Deposit Models. U.S. Geological Survey Bulletin, 1693, p. 379.

[19] Shahabpour, J. (2001) Economic Geology. Shahid Bahonar University of Kerman, Kerman, p. 543.

Submit or recommend next manuscript to SCIRP and we will provide best service for you:

Accepting pre-submission inquiries through Email, Facebook, LinkedIn, Twitter, etc. A wide selection of journals (inclusive of 9 subjects, more than 200 journals)

Providing 24-hour high-quality service

User-friendly online submission system

Fair and swift peer-review system

Efficient typesetting and proofreading procedure

Display of the result of downloads and visits, as well as the number of cited articles Maximum dissemination of your research work

Submit your manuscript at: http://papersubmission.scirp.org/

Or contactojg@scirp.org 